\title{
Poverty on the Periphery: U.S. Implementation of Modernization Theory in the Alliance for Progress and the War on Poverty
}

\author{
Michelle C. Mayhew \\ West Virginia University
}

Follow this and additional works at: https://researchrepository.wvu.edu/etd

\section{Recommended Citation}

Mayhew, Michelle C., "Poverty on the Periphery: U.S. Implementation of Modernization Theory in the Alliance for Progress and the War on Poverty" (2013). Graduate Theses, Dissertations, and Problem Reports. 498.

https://researchrepository.wvu.edu/etd/498

This Thesis is protected by copyright and/or related rights. It has been brought to you by the The Research Repository @ WVU with permission from the rights-holder(s). You are free to use this Thesis in any way that is permitted by the copyright and related rights legislation that applies to your use. For other uses you must obtain permission from the rights-holder(s) directly, unless additional rights are indicated by a Creative Commons license in the record and/ or on the work itself. This Thesis has been accepted for inclusion in WVU Graduate Theses, Dissertations, and Problem Reports collection by an authorized administrator of The Research Repository @ WVU. For more information, please contact researchrepository@mail.wvu.edu. 
Poverty on the Periphery: U.S. Implementation of Modernization Theory in the Alliance for Progress and the War on Poverty

Michelle C. Mayhew

Thesis submitted to the College of Arts and Sciences at West Virginia University in partial fulfillment of the requirements

for the degree of

\author{
Master of Arts \\ in \\ History
}

\author{
James Siekmeier, Ph.D., Chair \\ Mark Tauger, Ph.D. \\ Kenneth Fones-Wolf, Ph.D. \\ Department of History
}
Morgantown, West Virginia
2013

Keywords: Alliance for Progress; War on Poverty; Modernization Theory Copyright 2013 Michelle C. Mayhew 


\begin{abstract}
Poverty on the Periphery: The U.S. Implementation of Modernization Theory in the Alliance for Progress and the War on Poverty
\end{abstract}

\author{
Michelle C. Mayhew
}

The principle objective of this paper is to compare how modernization theory was implemented during the Alliance for Progress and the War on Poverty and to explore how this impacted power structures at the national level in the Alliance and the local level in the War on Poverty There have been some earlier works which have addressed modernization theory during the Alliance for Progress, including Michael Latham's, Modernization as Ideology, however most information about modernization theory itself comes from W.W. Rostow's work, The Stages of Economic Growth, and Rostow and Millikan's, A Proposal. During the War on Poverty, President Johnson also utilized modernization theory; though current scholarship focuses primarily on specific War on Poverty programs, such as Frank Stricker's, Why America Lost the War on Poverty-And How to Win It, or on the War on Poverty in specific areas of the country, such as David Whisnant's, Modernizing the Mountaineer.

While much work has been done about why the Alliance and the War on Poverty failed, there has been little looking at the connection between the two or how modernization theory impacted the making of policy. I seek to explore the relationship between these two programs and how modernization theory was put into practice in each. In this paper, I argue that due to the way in which modernization theory was used to enact both the Alliance for Progress and the War on Poverty, traditional power structures were strengthened ensuring that, in the Alliance, the goal of creating democratic governments was never reached and in the War on Poverty, the attempt to include the poor more fully in the decision making process was never attained. Additionally, I argue that the very policies which were intended to bolster the democratic process instead led to a resurfacing of dictatorships throughout Latin America and a doubling down by political machines within the local governments affected by the War on Poverty, in order to more firmly hold onto power. 


\section{Table of Contents}

INTRODUCTION

MODERNIZATION THEORY IN PRACTICE: THE

ALLIANCE FOR PROGRESS

MODERNIZATION THEORY AT HOME: THE WAR ON

POVERTY

38

SAVING FACE AND RECOGNIZING LIMITATIONS 51

CONCLUSION

65 


\section{Chapter 1 Introduction}

The end of World War II was supposed to bring peace and prosperity to the United States and its allies. While peace slipped out of reach with the advent of Cold War conflict between the U.S. and the Soviet Union, the war years gave the United States a distinct advantage in terms of production, bringing economic success to families throughout the country. By 1945 the U.S. alone accounted for 40 percent of global production and between 1940 and 1944 the U.S. economy grew 75 percent. ${ }^{1}$ This wartime economic growth allowed many Americans to experience prosperity unlike ever before. Even as the war drew to a close, the increased demand for luxury goods — which had been unavailable during the war — kept production high and, among other factors, allowed for continued prosperity into the 1950s. However, midway through the 1950 s the economy sputtered and unemployment increased. In 1953-54, 1957-58 and again in 1960-61 the growth of the American economy slowed and across the nation men and women faced unemployment. ${ }^{2}$ While most Americans were able to bounce back from these recessions, at times becoming even better off than before they occurred, the ups and downs marked new challenges for the U.S. economy. The prosperity of the war and postwar period was slowing and though outsourcing would not become a household word for a few more decades, the process had already began as businesses were closing up shop in the United States and heading south to open factories in Mexico, where labor was cheaper and environmental regulations were lax. With the Cold War ever present lawmakers began to grapple with the idea that impoverished people the

\footnotetext{
${ }^{1}$ Wyatt Wells, American Capitalism, 1945-2000: Continuity and Change from Mass Production to the Information Society, (Chicago: IVAN R. DEE, 2003), 5-6.

${ }^{2}$ Lizabeth Cohen, A Consumer's Republic: The Politics of Mass Consumption in Postwar America (New York:

Vintage Books, 2004), 121.
} 
world over made more willing converts to communism then did those who lived in prosperity. The Cuban revolution, which ended when Fidel Castro seized power in January 1959, made this possibility all the more present and within Washington guideline papers noted the vast chasm between the poor and the wealthy, as well as how "The poor and underprivileged... are now demanding opportunities for a decent living."3 With this in mind, poverty took on a new meaning. At home, governments sought to implement policies which would give everyone a “bigger slice of the pie," policies which President Johnson stated would, by "helping some... increase the prosperity of all." 4 In Latin America nations which had been close allies during the war became restless watching the United States pour billions of dollars into Europe and Japan, but spend what seemed only pennies to help their neighbors. In both cases it became clear that the United States government had to do something to implement change.

What form this change would take was still a question that was open for debate throughout the 1950s. However, by the end of the decade focus had begun to center on ideas being researched by the Center for International Studies at Massachusetts Institute of Technology. At the forefront of this research were economists Walt Whitman Rostow and Max F. Millikan. The research these men and their team undertook was focused on the "economic, social, and political processes involved in the efforts most of the so-called underdeveloped countries are making to raise their living standards." 5 The policies that they promoted became known as modernization theory and, with some modification, became the basis for U.S. foreign

\footnotetext{
${ }^{3}$ Summary Guidelines Paper, Washington, July 3, 1961. Foreign Relations of the United States, Volume XII, American Republics, Document 15.

${ }^{4}$ Lyndon B. Johnson, "Special Message to Congress Proposing a Nationwide War on the Sources of Poverty," March 16, 1964. Online by Gerhard Peters and John T. Woolley, The American Presidency Project.

${ }^{5}$ W.W. Rostow and Max F. Millikan, A Proposal: Key to an Effective Foreign Policy, (New York: Harper and Brothers, 1957), vii.
} 
aid policy in the Third World. Yet while modernization theory's role in the third world has been well documented, the ideas behind this theory also became the basis for significant portions of domestic policy during the 1960s, particularly in Appalachia.

The policy which most readily embraced modernization theory was announced by President John F. Kennedy on March 13, 1961—The Alliance for Progress. Less than three years later, after Kennedy was assassinated and Lyndon Johnson assumed the presidency, Johnson also announced a program which relied heavily upon modernization theory-The War on Poverty. Both programs drew inspiration from President Roosevelt's New Deal, which had been the U.S. government's first major aid effort and which held as one of its foremost goals helping people to help themselves through public works projects, job retraining, and agricultural incentive programs, instead of simply giving hand-outs. Both the Alliance for Progress and the War on Poverty shared a belief that people's lives could be improved long-term through modernization.

However, while there was much optimism at the outset of each program, this quickly faded away as it became obvious that change would require more than an overnight effort. As enthusiasm waned, the goals of democracy and political participation faded to the background. Instead, the implementation of the Alliance for Progress and the War on Poverty gave local elites the power they needed to prevent modernizing efforts and reforms from truly taking hold, this proved to be counterproductive to the original goals of both the Alliance and the War on Poverty and led only to stagnation, not to the peaceful revolutions which had been promised. With this desire of politicians to preserve the status quo at every level possible, even small reforms took 
tremendous effort and capital to enact, thus limiting how successfully modernization theory could be put in place.

At the heart of modernization theory lay the five stages of growth. These consist of: (1) the traditional society, (2) societies with the preconditions for take-off, (3) the take-off stage, (4) the drive to maturity, and (5) the age of high mass-consumption. ${ }^{6}$ In order to industrialize and modernize, a nation must move from the position of a traditional society or a society with the preconditions for take-off into the take-off stage and then, on towards maturity. For this to happen, a number of prerequisites must be in place, including a growth of savings which makes it possible for individuals to invest capital in new ventures outside of agriculture. Additionally, an agricultural sector which is capable of providing the food needed to fuel the country's growth is necessary. Left to its own devices, this process took substantial amounts of time, at times even a hundred years or more. However, developed nations could assist other nations in reaching the take-off stage by providing loans and aid, thereby allowing for a quicker build-up of the funds necessary for industrialization and other costs associated with growth. ${ }^{7}$ Yet modernization theory was not an idea that advocated for the United States or any other developed nation to intercede and "fix" the problem. Instead, Rostow clearly states that, "In the end, however, the task of development must be done by those on the spot." ${ }^{8}$ Rostow and Millikan explained the responsibility of the developed nation in this way:

\footnotetext{
${ }^{6}$ W.W. Rostow, The Stages of Economic Growth: A Non-Communist Manifesto, $2^{\text {nd }}$ ed. (Cambridge: Cambridge University Press, 1971), 4-10.

${ }^{7}$ Rostow, 49-50.

${ }^{8}$ Ibid., 144.
} 
While it is obvious that the political, social, and economic development of foreign areas is a task for the peoples of these areas themselves...two considerations suggest that it would be inexcusable for the United States and the other developed nations of the Free World not to exert to the utmost whatever influence they have. In the first place, we have a compelling national interest in promoting a world environment in which we ourselves can live freely...In the second place, American society is at its best when we are wrestling with the positive problems of building a better world. ${ }^{9}$

While it is clear that Rostow and Millikan intended for the United States to lead the efforts forward, this also suggests that in order for modernization to be truly successful it is necessary that it be owned by the nation or area that is modernizing. This is emphasized further through the recognition that, "Perhaps the most critical requirement for the growth of political maturity is that the people of the new nations develop confidence, both as a nation and as individuals in small communities, that they can make progress with their problems through their own efforts." 10 This acknowledgment of the role that had to be played by the men and women who lived in a given nation or region can be equated with the idea of self-help. Rostow and Millikan stress this when they state, “...the bulk of the task must be done by the people of the developing country itself. They must develop the necessary institutions, generate the required energy and initiative, acquire the requisite wisdom and courage in planning and controlling resource use, learn the necessary skills and techniques." ${ }^{11}$ In doing all of these things, people in a given region would be able to look back and recognize that they solved their own problems. For many in the United States and abroad, this was a selling point—self-help was not a hand out,

\footnotetext{
${ }^{9}$ Rostow and Millikan, 7.

${ }^{10}$ Rostow and Millikan, 31.

${ }^{11}$ Rostow and Millikan, 59.
} 
it was an opportunity for others to do as most believed the United States had done earlier and lift themselves up by the bootstraps, so to speak. While modernization theory was developed as an approach the United States could take in its relations with the developing world, the schema that Rostow and Millikan created could also be applied to domestic development within areas of the United States that were underdeveloped. As policy both foreign and domestic was formed, the idea that people in an area would best be able to solve the problems they were facing played an increasing role in the expectations of individuals and of the U.S. government.

The first substantial attempt to utilize modernization theory as part of U.S. foreign policy came with President Kennedy's announcement of the Alliance for Progress. His speech, made to a room full of Latin American diplomats and members of the United States Congress, was greeted with much applause, hope and enthusiasm. In it, he drew inspiration from great American leaders who had come before him—from Simón Bolívar to Thomas Paine to Benito Juárez-President Kennedy spoke of the necessity of hemispheric solidarity so that all people of the Americas might be able to meet their basic needs. In ten points, Kennedy laid the groundwork for what he believed would be a program capable of attacking the blights of everything from illiteracy to poor health care to slow economies and which would raise the standard of living for all families. In this speech, Kennedy also called upon the principles of capitalism in order to ensure Latin American economic integration while at the same time highlighting the principle of self-help as a way for the men and women of Latin America to escape from their poverty. He stated that, “...only the most determined efforts of the American nations themselves [could] bring success to this effort. They, and they alone, can mobilize their resources, enlist the energies of their people, and modify their social patterns so that all, and not 
just a privileged few, share in the fruits of growth." $" 12$ This call sounded eerily similar to Rostow, who was at this point serving as Kennedy's deputy national security advisor, and Millikan's discussion of what would be required of the developing nations. In order to meet this challenge, individuals, not just governments, would have to make the choice to help themselves.

Yet all nations were not created equal, nor would all have equal opportunity to help themselves. Though Kennedy spoke of helping all Americans, funding was not distributed equitably to small and large nations. During the span of time from 1961-1967 Brazil received some 1.9 billion dollars in loans and other forms of aid, while during the same time period, Panama, a much smaller and less prosperous nation, received only 60.1 million, or about three percent of what Brazil received. Still no small commitment, but during the single year from 1966-1967, Chile received 196 million and Brazil received 324.3 million. ${ }^{13}$

The disproportionately larger amounts of aid that the US gave to the larger and more powerful countries appears to be explained by a Department of State Guidelines paper from May, 1962. The paper emphasized the security connection between North and South America, and highlighted that the Alliance for Progress should "strengthen the inter-American system and cultivate closer relations with all Latin American countries and peoples, especially with those key nations which appear destined to play an important role in the hemisphere and in the world, such as Brazil, Argentina, and Mexico."14 Thus in many ways the Alliance, which was supposed

\footnotetext{
${ }^{12}$ John F. Kennedy: "Address at a White House Reception for Members of Congress and for the Diplomatic Corps of the Latin American Republics.", March 13, 1961. Online by Gerhard Peters and John T. Woolley, The American Presidency Project. http://www.presidency.ucsb.edu/ws/?pid=8531.

${ }^{13}$ The Committee on Government Operations, U.S. Aid Operations in Latin American under the Alliance for Progress, $90^{\text {th }}$ Congress, $2 \mathrm{~d}$ session, 3, 5, 7, 19.

${ }^{14}$ Department of State Guidelines Paper, Washington, May 1962. Foreign Relations of the United States, Volume XII, American Republics, Document 45.
} 
to encourage both democracy and economic development in all nations chose instead to focus its efforts and money on the larger, more powerful nations. This closely mirrored earlier alliances of mutual security. In part, this was due to a belief held by many U.S. policymakers that economic difficulties in Latin America would automatically lead to violence and political problems, and economic or political difficulties in the largest nations would be more disruptive to U.S. plans than those in smaller nations. As in those previous pacts, smaller and poorer nations were relegated to a lower position than the large and powerful countries from which the United States could more easily benefit.

When, nearly three years later, President Lyndon B. Johnson declared an "unconditional war on poverty in America"15 during his State of the Union Address, the ideas associated with modernization which had formed a basis for the Alliance for Progress were still present. While Rostow and Millikan focused on foreign policy in their work A Proposal, in Rostow's, The Stages of Economic Growth, the author noted a difference between the United States as a whole and the take-off of the American South as a separate entity, calling it "a phenomenon of the last two decades"16 after discussing only a few pages earlier that the United States had entered the take-off stage in the "several decades preceding 1860."17 Thus, just as the American South was late to the take-off stage, so too were other areas of the United States which were smaller and more isolated than the South. Rostow further noted the role that extractive industries have played in establishing the preconditions for take-off. While he discussed specifically the role of

\footnotetext{
${ }^{15}$ Lyndon B. Johnson: "Annual Message to the Congress on the State of the Union" January 8, 1964. Online by Gerhard Peters and John T. Woolley, The American Presidency Project. http://www.presidency.ucsb.edu/ws/index.php?pid=26787.

16 Rostow, The Stages of Economic Growth, 18.

${ }^{17}$ Ibid., 9.
} 
cotton in the American South, one could just as easily use Rostow's model to explain the role that coal and timber have played in Appalachia.

In addition to similarities between both foreign nations and domestic regions in terms of preconditions for take-off, President Johnson also adapted the concept of self-help to his domestic policy. Two months after his State of the Union, when President Johnson announced the War on Poverty he extolled the program as one which was "not a struggle simply to support people, to make them dependent on the generosity of others" ${ }^{18}$ but one which, instead, encouraged men and women countrywide to join together and "prepare long-range plans for the attack on poverty in their own local communities." ${ }^{, 19}$

These domestic plans derived from the same approach that Rostow and Millikan advocated in A Proposal: the necessity of "consistent and detailed national development programs ${ }^{\prime 20}$ that provided information about development projects. When done correctly, these plans specified particular projects and their projected costs. Like the international aid plans, the domestic plans of the Johnson era established a plan of action and determined how much it would cost to implement. These plans were similar in scope to those which President Kennedy called for when he stated that, "...if our Alliance is to succeed, each Latin nation must formulate long-range plans for its own development, plans which establish targets and priorities, ensure monetary stability, establish the machinery for vital social change, stimulate private activity and

\footnotetext{
${ }^{18}$ Lyndon B. Johnson, "Special Message to the Congress Proposing a Nationwide War on the Sources of Poverty," March 16, 1964. Online by Gerhard Peters and John T. Wooley, The American Presidency Project, http://www.presidency.ucsb.edu/ws/?pid=26109

${ }^{19}$ Lyndon B. Johnson, "Special Message to the Congress Proposing a Nationwide War on the Sources of Poverty," March 16, 1964. Online by Gerhard Peters and John T. Wooley, The American Presidency Project, http://www.presidency.ucsb.edu/ws/?pid=26109

${ }^{20}$ Rostow and Millikan, 61.
} 
initiative, and provide for a maximum national effort. ${ }^{, 21}$ In both the Alliance for Progress and the War on Poverty, policy makers understood that the plans that nations and communities put forward would necessarily be different as they sought to deal with the challenges that each faced.

In past works, historians have explored the Alliance for Progress from many different angles, but almost across the board have agreed that the Alliance was a failure. Historians such as Jerome Levinson and Juan de Onís have explored the role which development played in the creation of Alliance for Progress policy. While they do not specifically mention modernization theory, Levinson and Onís discuss how and why the Alliance failed to live up to the expectations that it would move Latin American nations ahead economically, socially, and politically. In their book, The Alliance that Lost its Way, they present a Latin American view of how the Alliance was implemented and why it was unable to meet its goals. Their study exposes the disconnect that existed between United States expectations of nations and the realities of Latin American countries. This is not to say that Latin American nations were inherently incapable of progress; however, the United States' assumption that Latin American countries would automatically adopt a U.S. style of law and economy, as well as Latin American assumptions that the United States understood the Alliance in the same way they did created a chasm between what could be done and what the nations who met at Punta del Este expected to be done. For Levinson and Onís this gap, and the inability of the Alliance nations to bridge it, leads to the Alliance's final collapse.

\footnotetext{
${ }^{21}$ John F. Kennedy: "Address at a White House Reception for Members of Congress and for the Diplomatic Corps of the Latin American Republics.", March 13, 1961. Online by Gerhard Peters and John T. Woolley, The American Presidency Project. http://www.presidency.ucsb.edu/ws/?pid=8531.
} 
While Levinson and Onís see the Alliance as a failure due to its inability to live up to its goals, in his book The United States and the Development of South America, 1945-1975, Samuel Baily views the Alliance as an example of power politics. Baily discusses the Alliance as "a reactive policy of social, political, and economic reform designed to provide Latin America with an attractive alternative to Castroism and to immunize it from communism." 22 By encouraging the development of nations which were close to home, the United States could effectively counter Soviet policies elsewhere, or so the thinking went. In this viewpoint, the most important aspect of the Alliance ends up being its ability to prevent other nations from following Cuba, not its ability to bring lasting change to Latin America.

Like Baily, historian Jeffrey Taffet notes the part that power plays in U.S. foreign aid, asserting early in his book, Foreign Aid as Foreign Policy: The Alliance for Progress in Latin America, that policymakers seek to use aid to ensure compliance and noting the belief that, “...creating consent with enticements (carrots) can produce a far more satisfying relationship and a deeper level of cooperation." 23 These attempts to encourage other nations to follow the U.S. lead end up, according to Taffet, being unsuccessful during the Alliance for Progress. Instead, his work represents some of the most recent scholarship on the Alliance and further supports the idea that U.S. political ideations about what the Alliance should be-foremost, a tool to fight Communism - were far more important than the expressed desires to assist the poor and promote democracy.

\footnotetext{
${ }^{22}$ Samuel L. Baily, The United States and the Development of South America, 1945-1975 (New York: New Viewpoints, 1976), 83.

${ }^{23}$ Jeffrey F. Taffet, Foreign Aid as Foreign Policy: The Alliance for Progress in Latin America (New York: Routledge, 2007), Introduction, Section: The Attractions of Foreign Aid, Kindle edition.
} 
While these viewpoints recognize the role of development in the Alliance for Progress, neither mentions the idea of modernization theory as contributing to the Alliance or its failure. The historian Michael Latham argued for a direct connection between modernization and policies such as the Alliance for Progress. In his book, Modernization as Ideology, Latham discusses how dependency theorists have faulted the very use of modernization theory as a policy base for the failure of the Alliance itself and have argued that, "the past of today's industrial countries did not at all resemble the present of nations such as those in Latin America." ${ }^{24}$ Latham further connects this idea that Western nations can drive the development of the Third World with earlier explanations of Western superiority such as those Enlightenment ideas which provided "justifications of the need for an altruistic, benevolent West to provide both material assistance and moral tutelage to direct the course of the less 'advance'...,25 Together, these ideas directly dispute the belief that, since developed nations have already faced the challenges of economic, political and social development, they are now in a place where they can help other nations to move past these struggles quickly. However, if the challenges are different for nations now than they were for nations that developed a century ago, then there is no quick path to becoming a modern nation and modernization theory is essentially irrelevant as a fast track to development.

The literature about the War on Poverty is equally dismal, faulting President Johnson's 'Great Society' with failing to live up to expectations. Like the Alliance for Progress, the Great Society programs in general, and the War on Poverty in particular, were met with optimism from both the administrations enacting them and much of the public. Yet soon after they were enacted

\footnotetext{
${ }^{24}$ Michael E. Latham, Modernization as Ideology: American Social Science and "Nation Building" in the Kennedy Era (Chapel Hill: The University of North Carolina Press, 2000), 5.

${ }^{25}$ Ibid., 14-15.
} 
there was discussion as to whether the policies were truly anything new and as to whether the same programs could work in all regions. In this paper, I will focus primarily on how policies were enacted in the Appalachian region, which was one of the main targets for the War on Poverty.

For historian David Whisnant the policies of the War on Poverty were little different from those that were part of the New Deal or the New Frontier in that they maintained many of the same ideas about the necessity of outside intervention to "help" Appalachians. Throughout these programs, Whisnant notes that help came in the form of missionaries and industrialists, with consequences that were not understood at the times of implementation. ${ }^{26}$ As the War on Poverty was implemented, Whisnant explores the programs limitations in terms of Appalachia due to its early focus on inner cities. ${ }^{27}$ Instead of providing a different set of programs for each location, parts of the War on Poverty, such as community action, were meant to exist in any sort of environment as they would be shaped by the people who lived there in order to meet their needs. However, though these programs existed, Whisnant discusses at length their limitations and their inability to create lasting change. He states how even in the most active Community Action Programs, such as that in Mingo County, West Virginia, investigators concluded that "the CAP did not in any way affect the root causes of poverty in Mingo County."28

While the revisionist perspective of Whisnant views an effort to treat the symptoms instead of the causes as a significant contributing factor in the failure of the War on Poverty,

\footnotetext{
${ }^{26}$ David E. Whisnant, Modernizing the Mountaineer: People, Power, and Planning in Appalachia, Rev. ed. (Knoxville: The University of Tennessee Press, 1994), xix-xxi.

${ }^{27}$ Ibid., 95-96.

${ }^{28}$ Ibid., 111.
} 
Michael Harrington in his book, The Other America, argued that poverty was a result of the poor's inability to access the same resources as the wealthy. Harrington thereby helps to expand on anthropologist Oscar Lewis's "Culture of Poverty" theory. While Harrington notes that the original occurrence which caused some to remain impoverished while others progressed "was not individual and personal, but a social product, ${ }^{29}$ he also discusses how it ends up resulting in a "personal fate" ${ }^{, 30}$ where the children of the poor continue to get the same level of education as their parents and continue to work the same menial jobs that their parents worked because they are not prepared to do anything else. Harrington takes this further, noting that even when opportunities did arise, such a new school being built in a poor area, the "entire environment, their life, their values, do not prepare [the poor] to take advantage of the new opportunity." They therefore experience the same cycles of unemployment and underemployment which keep them from moving into the middle class.

While Harrington's ideas about a culture of poverty would suggest that there is little that could be done to change the situation of the poor, Frank Stricker, argued that the government's War on Poverty simply did not go far enough and that is why it failed. In his book, Why America Lost the War on Poverty—And How to Win It, Stricker, like Whisnant, views the government's programs as ignoring the true causes of poverty. In order to be successful at significantly decreasing poverty, he states that the government must “...work with movements that support redistribution of income away from the very rich and toward the poor, direct government job

\footnotetext{
${ }^{29}$ Michael Harrington, The Other America: Poverty in the United States (New York: The Macmillan Company, 1963), 9-10.

${ }^{30}$ Ibid., 9-10.

${ }^{31}$ Ibid., 9.
} 
creation, and government efforts to protect unionization and require higher pay."32 As the government failed to go this far, the structures which kept people poor stayed in place, ensuring the War on Poverty would be unable to make lasting changes.

There are also those who have noted that, in many ways, Johnson's War on Poverty-as well as the other programs of his Great Society — fell victim to the fighting in Vietnam. As the administration required more and more resources for its quagmire in Southeast Asia, those left behind for domestic policies dwindled. In his essay "LBJ, Germany, and "the End of the Cold War'" Frank Costigliola notes that with the Great Society, as well as with his foreign policy efforts in Europe, "LBJ's war in Vietnam undercut the possibilities for his reforms.",33

Yet while all these scholars provide differing reasons for why the War on Poverty did not succeed at eliminating poverty in the United States, they all share the conclusion that the War on Poverty was not successful. Therefore, like the Alliance for Progress, a program started with high hopes of permanent change, the War on Poverty slowly lost momentum and funding until the Nixon administration abandoned it completely.

The 1960s were supposed to be the "decade of development," yet the legacy of those years speaks to a different reality. At the start of the decade, the U.S. government had embraced modernization theory as a way to both combat Communism and modernize the nations of Latin America, as well as impoverished enclaves at home. It had coupled with modernization theory

\footnotetext{
${ }^{32}$ Frank Stricker, Why America Lost the War on Poverty -And How to Win It (Chapel Hill: The University of North Carolina Press, 2007), 5.

${ }^{33}$ Frank Costigliola, "Lyndon B. Johnson, Germany, and 'the End of the Cold War"' in Lyndon Johnson Confronts the World: American Foreign Policy, 1963-1968, ed. Warren I. Cohen and Nancy Bernkopf Tucker (Cambridge: Cambridge University Press, 1994), 207.
} 
the idea of self-help - that teaching a man to fish would serve the dual purposes of feeding him for a lifetime and preventing him from becoming a Communist. In both foreign and domestic policy, the tenants of modernization theory were viewed as the way to achieve multiple objectives at once- the government could build up democracies, prevent Communism, promote capitalism and fight poverty all by implementing one set of policies. Yet by the beginning of 1970 illiteracy was still rampant, children still dropped out of school before completing the Alliance recommended six years, Latin American growth had not reached the 2.5 percent a year mark, men and women in Appalachia were still jobless, and the number of houses built still did not meet the needs of nations that were experiencing high population growth. The "decade of development" was a bust. 


\section{Chapter 2 Modernization Theory in Practice: The Alliance for Progress}

By the time John F. Kennedy assumed the presidency, the United States' relationship with the majority of its southern neighbors was in shambles. The high point of diplomatic relations and hemispheric respect had come years earlier under the Good Neighbor Policy of Franklin D. Roosevelt. For a brief moment, the nations of Latin America had been able to expect that the United States would keep out of Latin American domestic affairs more often than it would intervene. The good will created during this time frame helped to ensure that, when the United States entered World War II, it did so with the support of most of the Latin American nations. This support translated into preferential terms of trade for the United States during the course of the war on necessary raw materials ranging from food stuffs to tin. The expectation was that the United States would provide economic assistance to Latin America at the conclusion of the war. Historian Stephen Rabe notes in his book, Eisenhower and Latin America, that the United States had "...pledged that, once the enemy was defeated, it would support the economic development and diversification of Latin America."34 Yet the end of the war took the United States across the ocean to Europe and Japan and aid to the nations of Latin America was not forthcoming. In fact, Rabe notes that "between 1945 and 1952 the twenty Latin American nations together received less economic aid from the United States than did Belgium and tiny Luxembourg." 35

Instead, in the years following the Second World War the United States' policy in Latin America was distinctly hands-off, in terms of economic aid. According to C. Douglass Dillon,

\footnotetext{
${ }^{34}$ Stephen G. Rabe, Eisenhower and Latin America: The Foreign Policy of Anticommunism (Chapel Hill: The University of North Carolina Press, 1988), 12.

${ }^{35}$ Ibid., 17.
} 
who served as Under Secretary of State for Economic Affairs under President Eisenhower and Secretary of the Treasury under Kennedy, the policy of the United States prior to the election of Kennedy was "...that the countries of Latin America had prospered during the war and, with the sole exception of technical assistance, needed no economic aid that could not be provided by hard loans from the World Bank or from our own Export-Import Bank." ${ }^{36}$ Yet this was a pseudo-prosperity. While the nations of Latin America had been able to sell their goods to the United States during the war, they did so at fixed prices. Furthermore, Rabe notes that over the course of the war, "Latin Americans accumulated credits of $\$ 3.4$ billion, because the capital goods they wanted to purchase were scarce in the United States. This influx of money contributed to inflationary pressures, with the cost of living rising over 80 percent in Latin American during the war." 37 While the United States promised not to abruptly end contracts and to be open to negotiating prices when the war was finally over "after the war, the United States abruptly lifted price controls and prices rose rapidly; Latin America quickly exhausted its wartime credits." 38

In addition to inflationary problems and spent credits, Dillon's statement also fails to recognize that the war years had not led to extensive economic diversification or the blossoming of a plethora of value added industries. Instead, Latin American nations had intensified mining efforts and other labor intensive fields and sold billions of dollars of raw materials to Allied forces and received few long term benefits from doing so. At war's end, the Latin American nations were left with exhausted mines and expanding populations, but no outlets. The minerals

\footnotetext{
${ }^{36}$ C. Douglass Dillon, "The Prelude" in The Alliance for Progress: A Retrospective, ed. L. Ronald Scheman (New York: Praeger, 1988), 63.

${ }^{37}$ Rabe, Eisenhower and Latin America, 16.

${ }^{38}$ Rabe, Eisenhower and Latin America, 16.
} 
and metals they had sold to the Allies could have fetched a higher price on the open market, yet Latin America had, with few exceptions, stood by the United States, believing that the conclusion of the war would bring economic assistance. The picture of flourishing economies throughout Latin America was more myth than reality.

While money for development was out of the question, money for the military flowed unabated. This was in line with President Dwight D. Eisenhower's Latin American policy which sought to ensure a relationship with Latin American nations which would prevent communist infiltration in the hemisphere. Taking many cues from the policy of his predecessor, President Harry Truman, Eisenhower's administration offered “money, medals, and military support to Latin American leaders who were anti-Communists..."39 This type of "hemispheric solidarity" came at a cost, however, as President Eisenhower was willing to work with anti-communist leaders regardless of how they came to power or whether they were dictators or leaders of democracies. His administration often praised men who regularly restricted civil rights, including awarding the Legion of Merit, which is awarded to both U.S. service members and citizens of other nations who "have distinguished themselves by exceptionally meritorious conduct in the performance of outstanding service" to Venezuelan dictator, Pérez Jiménez. ${ }^{40}$

While the United States continued to put off the development of Latin America for later, Latin Americans themselves were taking a lead in pursuing new avenues of modernization and cooperation. In 1954 a group led by Argentine economist Raúl Prebisch prepared recommendations for Latin American development based on a report done by the United Nations

\footnotetext{
${ }^{39}$ Rabe, Eisenhower and Latin America, 26.

${ }^{40}$ Air Force Personnel Center, "Legion of Merit," Air Force Personnel Center, http://www.afpc.af.mil/library/factsheets/factsheet.asp?id=7732 (accessed May 23, 2013).
} 
Economic Commission for Latin America (ECLA). ${ }^{41}$ The recommendations included many of the same things which would become central themes of the Alliance for Progress, including "an annual foreign investment level of $\$ 1$ billion for ten years" and "national planning to establish priorities and allocate investments. ${ }^{242}$ Four years later, in May of 1958, Juscelino Kubitschek the president of Brazil set forth the problems of the Americas and called for change in a letter that he wrote to President Eisenhower. In his letter, he referred to the necessity of developing Pan Americanism, but admitted at this point that he had, "no definite and detailed plans to that effect, but rather ideas and thoughts..." Instead, President Kubitschek stated "that the hour has come for us to undertake jointly a thorough review of the policy of mutual understanding on this Hemisphere and to conduct a comprehensive reappraisal of the proceedings already in motion for the furtherance of Pan American ideals in all their aspects and implications." ${ }^{, 43}$ By August of 1958 Kubitschek had refined the ideas he wrote about to President Eisenhower into "Operation Pan-America" and had sent out a memorandum to the countries of the Americas defining and explaining the program. ${ }^{44}$ Felipe Herrera, the Inter-American Development Bank's first president, notes that "the foundations for the creation of an inter-American bank and of regional markets in the hemisphere were set forth in this document." ${ }^{45}$ When the United States finally decided it was time to invest in Latin America, it was these ideas and proposals which would form the backbone of U.S. policy.

\footnotetext{
${ }^{41}$ Levinson and de Onís, 38-42.

${ }^{42}$ Ibid., 40-41.

${ }^{43}$ Dwight D. Eisenhower, "Exchange of Letters Between the President and President Kubitschek of Brazil," June 10, 1958. Online by Gerhard Peters and John T. Woolley, The American Presidency Project, http://www.presidency.ucsb.edu/ws/?pid=11089.

${ }^{44}$ Felipe Herrera, "Principles and Performance," in The Alliance for Progress: A Retrospective, ed. L. Ronald Scheman (New York: Praeger, 1988), 89-90.

${ }^{45}$ Ibid., 89-90.
} 
This began to happen in May 1958 after Vice-President Richard Nixon's ill-received Central and South America goodwill tour. During his visit the car in which Nixon was travelling was attacked in Venezuela. The protests and mobs that Nixon experienced were a result of more than a decade of U.S. policies that focused primarily on anti-communism at the expense of democratic governments and failed to take into account the Latin American economic situation. The United States' continuous funding of militaries at the expense of social programs had led to dismal relations. In his article "Theory Gets Real, and the Case for a Normative Ethic: Rostow, Modernization Theory, and the Alliance for Progress" political scientist Piki Ish-Shalom expands on this, stating that, "The unwillingness of U.S. governments to develop the equivalent of the Marshall Plan for Latin America, and the United States focus on the Cold War and anticommunist agenda, led to feelings of ill treatment by Washington among the governments and citizens of Latin America." 46 In addition to the mistreatment discussed by Ish-Shalom, historian Walter LaFeber discusses in his work Inevitable Revolutions: The United States in Central America, how the United States Ambassador to Cuba, Philip Bonsal, pointed out that United States ownership of everything from electric and telephone companies to oil refineries and the sugar industry in nations such as Cuba bred resentment. ${ }^{47}$

After the vice-president's trip, President Eisenhower concluded that something had to be done in order to change the situation in Latin America. Historian Stephen Rabe notes that Eisenhower quickly began to adjust his policy and "Instead of awarding medals to dictators...began to express publicly his preference for political democracy and respect for

\footnotetext{
${ }^{46}$ Piki Ish-Shalom, "Theory Gets Real, and the Case for a Normative Ethic: Rostow, Modernization Theory, and the Alliance for Progress" International Studies Quarterly 50 (2008), 294.

${ }^{47}$ Walter LaFeber, Inevitable Revolutions: The United States in Central America, $2^{\text {nd }}$ ed. (New York: W.W. Norton and Company, 1993), 144.
} 
human rights." ${ }^{48}$ In order to combat the growing economic problems, Eisenhower's administration presented a new program for economic development to an inter-American economic conference in Bogotá in $1960{ }^{49}$ This program helped to establish the Inter-American Development Bank, which was meant to increase the funds available to Latin American nations for infrastructure development projects. Additionally, Eisenhower created the Social Progress Trust Fund in order to improve education and ease poverty in the region. This $\$ 500$ million investment came at the end of Eisenhower's term and was portrayed as a "down payment for a future, comprehensive effort" by Undersecretary C. Douglas Dillon. ${ }^{50}$ During this conference, the United States delegation also obtained the necessary support of Latin American nations for a resolution which became known as the Act of Bogotá. This Act sought to change and modernize the tax structures of Latin American countries. ${ }^{51}$

Yet at roughly the same time that Eisenhower was working to implement these new measures, Fidel Castro was leading a revolution in Cuba against U.S. backed dictator Fulgencio Batista. For those who had not previously seen a need to give economic aid to Latin America, Castro's rise to power and his subsequent efforts to build a close relationship with the Soviet Union convinced many that the Cuban Revolution could serve as a springboard for revolutions elsewhere in Latin America. After all, his revolution had established that there was an environment of desperation in Latin America. Both unemployment and underemployment were rampant and, as discussed earlier, U.S. ownership of basic services throughout Cuba caused a lot of resentment.

\footnotetext{
${ }^{48}$ Rabe, Eisenhower and Latin America, 105.

${ }^{49}$ Ibid., 142.

${ }^{50}$ Ibid., 149.

${ }^{51}$ Ibid., 143.
} 
However, it was not only in Cuba that the U.S. owned companies that caused locals bitterness, throughout Central and South America U.S. companies owned phone lines, railways and other basic services. Together with employment issues and a poor standard of living, this foreign ownership showed men and women throughout Latin America the necessity for change. The Cuban Revolution, which came to a culmination in 1959, showed the world that change which did not happen peacefully would happen by revolution, a U.S. fear which was made spectacularly real through Castro's actions. As Castro became stronger, this view gained more followers and in President Kennedy's announcement of the Alliance for Progress in March, he spoke to this concern stating “...we confront the same forces which have imperiled America throughout its history — the alien forces which once again seek to impose the despotisms of the Old World on the people of the New."52 It seemed Kennedy had conveniently forgotten U.S. attempts to enforce its own will upon Latin America, choosing instead to focus upon creating a commonality between the United States and its southern neighbors as they stood together to face the threat of Communism that was being forced upon Latin America from the Soviet Union-a nation which, as well as any, could be construed to represent Old World Europe.

Even before the newly elected Kennedy could formally take office, the problems of Latin America-U.S. relations were presented to him by the Task Force on Immediate Problems of Latin America. On January 4, 1961 this task force presented a report which stated that, upon inauguration, the new administration needed to "(a) emphasize its vivid interest in Latin America, (b) outline forcefully a line of approach, (c) provide, administratively, top-level

\footnotetext{
52 John F. Kennedy: "Address at a White House Reception for Members of Congress and for the Diplomatic Corps of the Latin American Republics.", March 13, 1961. Online by Gerhard Peters and John T. Woolley, The American Presidency Project. http://www.presidency.ucsb.edu/ws/?pid=8531.
} 
direction for Latin American problems." ${ }^{53}$ With the Alliance for Progress, President Kennedy was able to do all three of these things.

President Kennedy's announcement of the Alliance was met with much excitement and anticipation. Kennedy stated that foremost among the goals of the Alliance was the progress of the Latin American nations. This progress was to include increased educational opportunities, combating disease, land reform, and greater economic integration. It was to transform the lives of men, women and children across the Americas and provide not just higher living standards for all peoples, but it would also create, for the nations of the Americas, "a period of self-sustaining growth." ${ }^{54}$

In this first speech on March 13, 1961 there was no direct mention of modernization theory. However before he ever gave the speech John F. Kennedy had already appointed Walt W. Rostow as his deputy national security advisor and, as evidenced by a memorandum he wrote to Kennedy on March 2, 1961, he was in contact with Kennedy about ways to modernize Latin America. Michael Latham notes that in the memo, "Rostow argued that, through a massive transfusion of foreign aid, the United States could drive more than 80 percent of Latin America's 'underdeveloped' populations into 'self-sustained' growth." ${ }^{55}$ Rostow would continue to advise Kennedy throughout his administration, moving from his position as deputy national security advisor to Chairman of the Policy Planning Council at the State Department.

\footnotetext{
${ }^{53}$ Report from the Task Force on Immediate Latin American Problems to President Elect Kennedy, Washington, January 4, 1961. Foreign Relations of the United States, 1961-1963, Volume XII, American Republics, Document 2. (italics original)

${ }^{54}$ Report from the Task Force on Immediate Latin American Problems to President Elect Kennedy, Washington, January 4, 1961. Foreign Relations of the United States, 1961-1963, Volume XII, American Republics, Document 2.

${ }^{55}$ Latham, 199. Reference to W.W. Rostow memorandum to John F. Kennedy, 2 March 1961, President's Office Files (POF), box 64a, "Rostow, 3/61-5/61, “ John F. Kennedy Library, Boston, Massachusetts (JFKL).
} 
In the first weeks after Kennedy's announcement speech, it seemed as if economic intervention based on modernization theory was going to replace military intervention in the United States' arsenal of ways to encourage change in Latin America. It furthermore seemed as through the U.S. was finally ready to respect Latin American sovereignty and to assist Latin America in achieving true change through the peaceful revolutions which would bring about the social changes which Kennedy so eloquently extolled. But then the U.S. followed through with the Bay of Pigs attack in April of 1961. While the attack had been planned by the CIA during President Eisenhower's administration, President Kennedy decided to move forward with the plan for a number of reasons, yet the end result was not the downfall of Castro, but the defeat of the U.S. supported forces who attempted the invasion. As it became clear that the U.S. had been involved in the attempted overthrow, Kennedy's words about how the Alliance for Progress would raise "the living standards of every American family," ensure that "basic education will be available to all," and that "hunger will be a forgotten experience" ${ }^{56}$ sounded hollow. The intervention had violated "the basic inter-American agreements [and] stunned the entire hemisphere as much because of its outcome as because of its auspices." 57 Thus by the time the governments of the Latin American nations and the United States met in Punta del Este, Uruguay in August of 1961 there was some concern about the sincerity of the U.S. position.

The proposals which the U.S. brought to the table that August were influenced substantially by modernization theory and they strongly supported the concept of self-help. In a

\footnotetext{
${ }^{56}$ John F. Kennedy: "Address at a White House Reception for Members of Congress and for the Diplomatic Corps of the Latin American Republics.", March 13, 1961. Online by Gerhard Peters and John T. Woolley, The American Presidency Project. . http://www.presidency.ucsb.edu/ws/?pid=8531.

${ }^{57}$ Levinson and de Onís, 60.
} 
speech written for the Inter-American Economic and Social Conference at Punta del Este, President Kennedy lauded the ideas of national planning and long-range development programs while noting that "nations of the north and nations of the south—must make new efforts of unparalleled magnitude" if countries were to attain "freedom and self-fulfillment of man.,"58 Upon return, Secretary of the Treasury Dillon, who led the U.S. delegation, reiterated in a memorandum to President Kennedy the importance of choosing the committee of development experts as quickly as possible so that they could begin reviewing countries' long-term development programs and uphold U.S. commitments to the region. Additionally, Dillon expressed a desire to retrain staff so that they would be prepared for the "continuous representational efforts and negotiations" which field staff would undoubtedly encounter when programs of reform were introduced. ${ }^{59}$

This preparation proved to be both sorely needed and entirely insufficient. The meeting at Punta del Este, Uruguay in August of 1961 had established a number of promising objectives and ideas. The meeting's "Declaration to the Peoples of America" stated that "This Alliance is established on the basic principle that free men working through the institution of representative democracy can best satisfy man's aspirations, including those for work, home and land, health and schools. ${ }^{960}$ It then went on to note the importance of social and economic development, fair wages and improved working conditions, better education, reformed tax codes, improved health care and sanitation, among a number of other changes which those who established the Alliance

\footnotetext{
${ }^{58}$ John F. Kennedy, "Message to the Inter-American Economic and Social Conference at Punta del Este, Uruguay," August 5, 1961. Online by Gerhard Peters and John T. Woolley, The American Presidency Project. http://www.presidency.ucsb.edu/ws/?pid=8271

${ }^{59}$ U.S. Department of State, "Memorandum from Secretary of the Treasury Dillon to President Kennedy," August 25, 1961. Foreign Relations of the United States, Volume XII, American Republics, Document 32 ${ }^{60}$ Alianza para el Progreso: The Record of Punta del Este, 1.
} 
for Progress viewed as important to improving the lives of men and women throughout the Americas. Yet while the "this is our goal" and the "these are the things that need done" were both recorded from the beginning, that first meeting at Punta del Este did little to establish the "how we get there." Yes, there were studies to be financed and committees to created, but the logistics of designating and distributing money and evaluating and approving projects were left to the side.

The conclusion of the meeting did nothing to ease this logistical problem, as can be seen in a memorandum of a conversation involving President Kennedy and members of the AID staff over six months later. During this conversation it is noted that, "There was an extensive discussion of the Alliance for Progress and the difficulties in getting it properly organized." year and a half after that, the problem of implementation still had not been remedied and a memorandum from Richard Goodwin, Secretary General of the International Peace Corps Secretariat, to President Kennedy reflects as much. In the memo, Goodwin states that, "It is increasingly disappointing that a program which is sound in conception and historically right is operating at about one-half effectiveness. (And that may be a generous estimate). ${ }^{, 62}$ He then discusses two concrete examples of the red tape which surrounded and hindered the Alliance. In one case he noted that a year prior it had been agreed that they would try out a "state-to-country program" using California and Chile, but that it took a full year to select a staff to implement the project. In a second example, he discussed how, despite having one of the largest loan programs

\footnotetext{
${ }^{61}$ Memorandum of Conversation, March 9,1962, Foreign Relations of the United States (FRUS) XII, American Republics, Document 42.

${ }^{62}$ Memorandum from the Secretary General of the International Peace Corps Secretariat (Goodwin) to President Kennedy, September 10, 1963, FRUS XII, American Republics, Document 63.
} 
in Latin America, the AID Director in Bolivia had waited for six months for a qualified loan officer. $^{63}$

The creation of the Inter-American Committee on the Alliance for Progress or CIAP, in 1963 helped to alleviate some of the problems that the Alliance was facing and, as a multilateral agency, gave Latin Americans a larger role in overseeing the Alliance. Foremost among the new agency's tasks was reviewing development plans and national progress, thus eliminating some of the bureaucracy that was hampering many governments from proceeding. ${ }^{64}$

While the government dawdled in getting the Alliance up to full capacity, the press also questioned how the program was supposed to be implemented. In a New York Times article from March 6, 1962 the question was posed as to what was supposed to come first “...United States aid or Latin-American reforms?" ${ }^{65}$ The discussion dealt with whether or not short-term aid should be given to nations which were submitting plans for modernizing their nations in terms of infrastructure and small social concessions, but were holding off on making deeper social, economic, and political reforms. Emphasis in the article was placed upon the situation in Chile, where the government of Jorge Alessandri had submitted an economic and social development plan to the Organization of American States (OAS) which was in line with the recommendations of the Alliance for Progress and had begun the process of land reform by submitting a plan to the Chilean Congress, yet as Chile waited, it also faced "an acute exchange crisis" ${ }^{66}$ for which Chile hoped to get short-term aid. Providing this aid would not be in line with the long term goals of

\footnotetext{
${ }^{63}$ Ibid.

64 "Summaries of Major U.S. Accomplishments," August 22, 1966, National Archives and Records Administration, RG 59, Pol 1 LA-US, Box 2416.

65 "The Alliance for Progress," New York Times, March 6, 1962, 34.

${ }^{66}$ Ibid.
} 
the Alliance, but might provide Chile with a better chance of successfully implementing programs which were within the scope of the Alliance for Progress. As a result of these policy questions, many of the Alliance's first projects seemed to be piecemeal efforts designed to address symptoms of the problem, but not the problem itself - in other words, the projects were designed to do exactly what the Alliance was designed to avoid.

One example of this can be seen in Rio de Janeiro and in Buenos Aires, where the governments of Brazil and Argentina initiated the building of new housing developments into which peasant families who were just moving from the countryside, as well as the poor who lived in slum like camps around the cities, could move. As Leandro Benmergui's documents in "The Alliance for Progress and Housing Policy in Rio de Janeiro and Buenos Aires in the 1960s" urban planners associated with the building projects were "deeply influenced by the general assumptions of the theory of modernization" when they published a manual for the peasants who would soon live in the homes to read in order to properly adjust to their new lifestyles. ${ }^{67}$ Over the course of the 1960s, there were roughly 9,000 housing units constructed in Rio de Janeiro and another 10,000 built in Buenos Aires. ${ }^{68}$ Once these units were completed, peasants were moved in and were expected to become productive, useful members of society. By moving to the cities and to new buildings with all the amenities of urban living, the peasant population was supposedly effectively modernized. The outcome was believed to be the following:

...societies were expected to become more rational and less emotional, they would be moderated in politics while state proceedings would be performed by an elite comprised

\footnotetext{
${ }^{67}$ Leandro Benmergui, "The Alliance for Progress and Housing Policy in Rio de Janeiro and Buenos Aires in the 1960s," Urban History 36 (2009): 304.

${ }^{68}$ Ibid., 304.
} 
of technocrats and politicians instead of irrational and populist leaders and the populace would incorporate the habits of mass consumption associated with a middle-class society. ${ }^{69}$

While it is true that these programs, and others like them, fit in with the objectives established for the Alliance, they often became muddled from politicking. The Alliance record from Punta del Este clearly stated in its list of objectives that it was necessary "To increase the construction of low-cost houses for low-income families in order to replace inadequate and deficient housing and to reduce housing shortages..." Yet this same objective notes that it is also necessary to provide "public services to both urban and rural centers of population.",70 Benmergui discusses how in this case, a planned industrial park that would have provided jobs was never created and that public transportation, which would have allowed the new residents to possibly find jobs in other parts of the city remained "notoriously poor." ${ }^{, 71}$ Despite this clear example of a failure to fully carry out a development and industrialization program, men such as Teodoro Moscoso, coordinator of the Alliance for Progress, and Lincoln Gordon, the U.S. Ambassador to Brazil, visited these projects and Mr. Moscoso noted that it was an opportunity for the people who settled in these communities to "assume new responsibilities" and to "obtain solid individual credit" as well as the chance to show that these homes could be "an example and incentive to others. ${ }^{, 72}$

\footnotetext{
${ }^{69}$ Ibid., 309.

${ }^{70}$ Inter-American Economic and Social Council (IA-ECOSOC), Alianza para el Progreso: The Record of Punta del Este, 1961: 5.

${ }^{71}$ Benmergui, 314-315.

72 Juan de Onis, "Brazilians Wary on Aid Benefits: Poor Still Skeptical after Moscoso Talk on Alliance," New York Times, August 19, 1962, 31.
} 
This position was further backed up by the U.S. government's "Study on International Housing" which suggested that, "Arrangements which encourage homeownership may stimulate investment that would not otherwise take place. Increased housing activity creates employment in building materials industries and the construction sector."73 They fail to mention that this increased employment would have been temporary and the same problems would have existed with the end of a construction boom as existed before it. Additionally, a letter from President Johnson to the head of the workers' housing bank, ASINCOOP, in Peru, illustrates how the idea that by providing housing, the government was somehow creating a middle class had reached the highest levels of government. In his letter, after commending ASINCOOP's efforts to encourage self-help and diminish the "gnawing problem of better houses" by giving long term, low interest loans to home owners, Johnson states that ASINCOOP, through its democratic ideals, is working to "give the Peruvian workers "the rug on the floor, the picture on the wall and music in the home,' to which all workers in our continent aspire."74

Yet while many questions remained about how the ideas and ideals of the Alliance could be put into practice, perhaps the most elusive of all was what constituted self-help. President Kennedy had proclaimed again and again the importance of Americans joining together to come up with plans which would better their communities. In his statement about Adlai Stevenson's mission to South America he stated, "In this effort each country needs first of all to help itself. But we must also help each other and move together." ${ }^{, 75}$ Less than three months later in the

\footnotetext{
${ }^{73}$ Subcommittee on Housing, Committee on Banking and Currency, US Senate, "Study of International Housing," $88^{\text {th }}$ Cong., $1^{\text {st }}$ sess., March $1,1963,88$.

${ }^{74}$ Letter from President Johnson to Mr. Felix Loli Cepero, AmConsulate Arequipa, July 2, 1964; National Archives and Records Administration, RG 59, 15-1, Johnson, Box 2830.

75 John F. Kennedy, "Statement by the President Concerning Adlai Stevenson's Special Mission to South America," May 29, 1961. The American Presidency Project
} 
statement he wrote to be delivered at Punta del Este Kennedy noted the importance of "selffulfillment" and stated that the success of the Alliance for Progress did not lie on governments alone, but that "Its success demands the participation of all our people — of workers and farmers, businessmen and intellectuals and, above all, of the young people of the Americas."76 Yet to Latin American nations even self-help seemed out of reach. By 1966, reactions to President Johnson's $5^{\text {th }}$ Anniversary speech discussed the necessity of the United States recognizing the “"fact' that self-help concept could not operate unless economic equilibrium established."77

In El Salvador, one of the first major loan projects of the Alliance for Progress was “...a private industrial development bank" which was intended to help the government to build a better relationship with the business community. ${ }^{78}$ In Argentina, loans were made for development projects and also to help pay back interest on loans which it was struggling to pay. ${ }^{79}$ In Bolivia and Venezuela, one area which received a significant amount of initial focus was the collection of taxes, with a memorandum from the Director of the Office of InterAmerican Regional Economic Affairs noting that "Tax collections in Bolivia were 17\% greater than in the previous year; in Venezuela tax revenues in 1961 were about $15 \%$ greater than in the previous year..."

\footnotetext{
${ }^{76}$ John F. Kennedy, "Message to the Inter-American Economic and Social Conference at Punta del Este, Uruguay," August 5, 1961. The American Presidency Project

${ }^{77}$ State Circular 30353, Guayaquil 157, August 19, 1966, National Archives and Records Administration, RG 59, Pol 15-1, President Johnson, Box 2840.

${ }^{78}$ Memorandum for the President: The Alliance for Progress in El Salvador, Washington. Foreign Relations of the United States, 1961-1963, Volumes X/XI/XII, Microfiche Supplement, American Republics; Cuba1961-1962, Cuban Missile Crisis and Aftermath, Document 120.

${ }^{79}$ Memorandum from the Director of the Agency for International Development (Hamilton) to President Kennedy, Washington, April 6, 1962. Foreign Relations of the United States, 1961-1963, Volume XII, American Republics, Document 183.

${ }^{80}$ Memorandum from the Director of the Office of Inter-American Regional Economic Affairs (Turnage) to the Assistant Secretary of the State for Inter-American Affairs (Martin), Washington, November 29, 1962. Foreign Relations of the United States, Volume XII, American Republics, Document 51.
} 
While all of these projects served one purpose or another, it is questionable whether they fell into the true spirit of self-help. A private industrial development bank was meant for those who already had capital to invest, though it could help the nation to generate greater capital than it had previously. Loans made to assist with balance of payment issues did little to nothing to benefit the average men and women of any nation, but served instead to ensure that governments could keep borrowing large quantities of money. Tax reform, while undoubtedly necessary was one of the requirements that governments had to meet in order to get Alliance funds in the first place. Though self-help had been lauded in speech after speech and had been included when the Alliance for Progress nations met at Punta del Este, discussions within the U.S. government were seeing it as falling short of its desired effects. In one discussion it was noted that, "Despite our talk of self-help, many government leaders in Latin America just don't take us seriously." 81

A month later, the question of self-help was beginning to move in another direction. By February 1962, the Secretary of State's Policy Planning Committee was already setting the United States on a path which would eventually lead the U.S. to move away from requiring real changes within countries which received aid by pointing out that, "It is difficult to determine how much self-help and reform we can insist upon in relation to the political limitations facing a recipient government." Stating further that, "At present, there is no correlation between per capita assistance received by countries and their performance in terms of self-help and reform criteria. Indeed, the most irresponsible countries... are the ones which have received the most assistance. We thus reward the irresponsible and discriminate against the responsible." 82

\footnotetext{
${ }^{81}$ Highlights of the First Meeting of the Working Group on the Alliance for Progress, Washington, January 16, 1962. Foreign Relations of the United States, 1961-1963, Volume XII, American Republics, Document 37. ${ }^{82}$ Highlights of Discussion at the Secretary of State's Policy Planning Committee Meeting, Washington, February 13, 1962. Foreign Relations of the United States, 1961-1963, Volume XII, American Republics, Document 40.
} 
This wavering commitment to self-help and reforms can be seen throughout government statements and discussions. While the government declared the necessity of long-range plans for growth, it gave small, short-term loans to nations like Bolivia. In a letter from President Kennedy to Bolivian President Victor Paz Estenssoro, Kennedy reiterated the U.S. commitment to assisting Bolivia in developing long-term plans for economic growth and then discussed the signing of a loan for " $\$ 3.5$ million to finance the purchase of urgently needed machinery and equipment" for the mining company COMIBOL. ${ }^{83}$ Additionally, Bolivia's oil company, Yacimientos Petrolíferos Fiscales Bolivianos (YPFB) was also getting an immediate loan for \$6 million. ${ }^{84}$ Overall, President Kennedy noted that the result of lending from all corners meant that "a total of some $\$ 50$ million in free world assistance is pledged to Bolivia." He went on to state that "The projects to be finances through this assistance are regarded by my Government as initial steps towards the realization of the longer-range program of economic development to which I have already referred." 85

Yet while Bolivia received all this aid within the first months of the Alliance, it becomes abundantly clear that even a year after the Alliance went into action, Bolivia had still not submitted a long-term development plan. In a memorandum from the Director of the Office of Inter-American Regional Affairs, William V. Turnage to the Assistant Secretary of State for Inter-American Affairs, Edwin M. Martin, on November 29, 1962 Turnage notes that, "All countries have taken appreciable steps toward the preparation of national development plans. Chile and Colombia have completed plans which have already been evaluated by the Panel of

\footnotetext{
${ }^{83}$ John F. Kennedy, "Letter to President Paz Estenssoro Concerning a Long-Range Program for the Development of Bolivia," May 15, 1961, The American Presidency Project, http://www.presidency.ucsb.edu/ws/index.php?pid=8127.

${ }^{84}$ Ibid.

${ }^{85}$ Ibid.
} 
Nine. The Panel is now considering plans submitted by Mexico and Venezuela." 86 Thus despite the short-term aid that Bolivia had received, it had not yet followed through with a long-term plan as required by the Alliance for Progress prior to receiving funding.

By 1963, the Alliance was facing increasing problems and doubts from leaders in Latin America as well as within the United States. In a New York Times article dated March 20, 1963, Dr. Juscelino Kubitschek, the former president of Brazil who had been instrumental in forming many of the ideas that came to be the basis of the Alliance, was quoted as saying that Alliance for Progress "is heading toward failure." 87 According to the brief article, this was due to poor planning and a lack of funding, though given the nearly 2 billion dollars that Brazil alone received, it seems that lack of planning and follow-through were more to blame than limited funding.

Then, in 1964, the U.S. government dealt another blow to the Alliance for Progress when President Johnson announced the Foreign Aid budget for 1965. In his message to Congress, Johnson stated that, "Two-thirds of the development lending proposed for fiscal 1965 (including Alliance for Progress lending) will be concentrated in six countries: Chile, Colombia, Nigeria, Turkey, Pakistan and India." 88 While it is possible that the other one-third of development funding could have been going to Alliance for Progress nations, and while there is no doubt that the amount earmarked for development was significant enough that even that one-third would be

\footnotetext{
86 "Memorandum from the Director of the Office of Inter-American Regional Economic Affairs (Turnage) to the Assistant Secretary of State for Inter-American Affairs (Martin), 'Washington, November 29, 1962, Foreign Relations of the United States, Volume XII, American Republics, Document 51.

${ }^{87}$ New York Times, March 20, 1963.

88 “Text of President Johnson's Foreign Aid Message to Congress," New York Times, March 20, 1964.
} 
a large sum, more importantly than how much money is going where, Johnson's statement seems to mark a shift in focus away from the Alliance.

Despite this apparent shift, ambassadors in Alliance nations continued to work hard at encouraging change, yet they too often questioned whether aid should be given prior to the approval of long-term plans in order to garner some short term improvements. Columbian Ambassador Covey T Oliver utilized modernization terms to discuss how "everything cannot wait for a 'take-off' GNP to generate the public sector savings needed right now in education and other social services." 89 Instead, to him it was imperative that those agencies which loaned money "make dollars available for local currency costs."90 This, in turn, would allow social change to take place and assist individuals in putting self-help into action in their own works.

The problems of the Alliance for Progress up to this point were both numerous and significant, but they were not unknown. They were discussed in newspapers, in meetings and in conversation, yet the solutions seemed no closer than they had been when the Alliance was first formed. In a report issued by the Inter-American Conference of Ministers of Labor in 1963, the delegate from Brazil noted that the only way to achieve structural reforms was through continuous social pressure. His explanation for why sums up why the Alliance had trouble moving forward not just in Brazil, but across Latin America. He stated that, "The elite cannot or will not carry out such reforms, or they adapt them to suit their own interests. If the social structure is unbalanced, no amount of economic development will suffice, and the elite do not

\footnotetext{
89 "Address to the Conference on Law Universities and Development in Latin America," Ambassador Covey T. Oliver, July 17, 1966, National Archives and Records Administration, RG 59, Pol 15-1, Johnson, Box 2840. ${ }^{90}$ Ibid.
} 
take a firm stand in support of the Alliance objectives." ${ }^{91}$ With the upper classes striving to hold onto their position within society and wary of fully supporting any program which might upset the social balance, the Alliance programs which garnered support were generally superficialthus houses were built and highways were built, but promises of agrarian reform and industrial parks went unfulfilled.

${ }^{91}$ Inter-American Conference of Ministers of Labor on the Alliance for Progress, "Final Report of the InterAmerican Conference of Ministers of Labor on the Alliance for Progress," May 11, 1963, National Archives and Records Administration, RG 43, Entry 184, Box 1. 


\section{Chapter 3 Modernization Theory at Home: The War on Poverty}

Instead, President Johnson's administration sought to be more focused on domestic affairs than had been his predecessor. He sought to tackle the issue of poverty amidst plenty that had captured the attention of Americans and to ensure that every member of society saw the benefits of the economic boom that the United States experienced post-World War II. President Johnson had a special interest in defeating poverty within the U.S. As a child, he had grown up in the impoverished hill-country of Texas, a land that stood in contrast to the gentle terrain and rich oil wells elsewhere in Texas. Though Johnson's family never experienced the desperate poverty of others in their region, Johnson still maintained a desire to help others help themselves. One of his first initiatives after being elected to the U.S. Senate was to bring water and electric to his rugged, hill-country district so that local farmers would have access to the resources they needed to make a living. ${ }^{92}$ Even at this early point of his career, the concept of self-help already existed within Johnson's political arsenal.

Johnson's belief in self-help made it a focal point in the collection of programs called the "Great Society," among which one of the best known of these was the War on Poverty. The first years of President Lyndon Johnson's War on Poverty, with its similar focus on self-help, resembled the Alliance for Progress under President Kennedy. When Johnson proposed his War on Poverty to Congress he stated that the Community Action Programs he was hoping to create were asking "men and women throughout the country to prepare long-range plans for the attack

\footnotetext{
${ }^{92}$ Rowland Evans and Robert Novak, Lyndon B. Johnson: The Exercise of Power (New York: The New American Library, 1966), 6-9.
} 
on poverty in their own local communities." 93 He further noted the importance of "...better schools, and better health, and better homes, and better training and better job opportunities..."94 in order to help Americans to escape from a cycle in which the children of the poor remained poor. These were some of the same issues that the nations which had met at Punta del Este had emphasized in the Charter of the Alliance for Progress.

Yet the War on Poverty was a program unto itself. While it shared many similarities with the Alliance for Progress it had its own background and predecessors, just as the Alliance had the Act of Bogota and Pan-Americanism. The desire to do something about poverty was not a new concept in the United States. Each president had sought to better the lives of his countrymen; it was the way in which one went about this that changed with administrations. Thus, forerunners of the War on Poverty included policies which stemmed from President Franklin Delano Roosevelt's New Deal campaign which included large public works projects such as dams and highways, as well as job retraining. The policies proposed after the "rediscovery" of poverty in the 1950s often looked nearly identical to their New Deal counterparts, such as Senator Paul H. Douglas's ideas about how to aid areas of the country which were economically depressed through "the federal government [underwriting] public works projects, job retraining, and business expansion in high unemployment areas" 95 and Senator Hubert H. Humphrey's proposal for a Youth Conservation Corps. ${ }^{96}$ The War on Poverty also included policies which were implemented under President Kennedy, such as the creation of the Area Redevelopment

\footnotetext{
${ }^{93}$ Lyndon B. Johnson, "Special Message to the Congress Proposing a Nationwide War on the Sources of Poverty," March 16, 1964. The American Presidency Project.

${ }^{94}$ Lyndon B. Johnson, “Annual Message to Congress on the State of the Union," January 8, 1964. The American Presidency Project.

${ }^{95}$ Carl M. Brauer, "Kennedy, Johnson, and the War on Poverty," The Journal of American History 69, no. 1 (June, 1982): 99.

${ }^{96}$ Ibid., 100.
} 
Administration (ARA) and the President's Appalachian Regional Commission (ARC). ${ }^{97}$ Both the ARA and the ARC were intended to study the Appalachian region and return recommendations about how to best address poverty in an area of the country considered to be especially depressed. While both were established under President Kennedy, the ARA in 1961 and the ARC as its successor in 1963, it was not until after President Kennedy's assassination that the ARC made recommendations about how to solve the problems of the Appalachian region, thus placing President Johnson in the position to pursue a solution to the region's problems.

President Johnson, who heard the committee's recommendations on April 9, 1964, responded to them in a speech to Congress less than three weeks later. By that winter, Congress accepted the Appalachian Regional Development Act of 1965 and Johnson then wasted no time in utilizing the Commission's suggestions to move forward with a plan for Appalachia, signing the Appalachian Regional Development Program into law on March 9, 1965. Tying in a program which established a "six-year Federal-State program to develop the economic potential of Appalachia" ${ }^{98}$ to his wider ideas about the War on Poverty, Johnson began work on his domestic program. In Appalachia, the ARC program meant a top down approach in which better roads and improved transportation would allow the area to become more open to industry, thereby providing both jobs and growth. Throughout the region, this approach was greeted with open arms by business leaders and politicians as many shared the ARC belief that, "Transportation, thus, in the history of the country, has been the key to opening up new areas for

\footnotetext{
${ }^{97}$ Appalachian Regional Commission, Appalachian Regional Commission Annual Report, 1966, Appalachian Regional Commission (Washington, D.C. July 1, 1965- June 30, 1966).

${ }^{98}$ Appalachian Regional Commission Annual Report, 1966, 4.
} 
development." 99 The ARC worked fast to make sure that the benefits of improved transportation reached the hills of Appalachia as quickly as possible and on July 6, 1965, only four months after the program became law, ground breaking ceremonies for the new Appalachian Highway system were held simultaneously in Isom, Kentucky and Salem, West Virginia. ${ }^{100}$

In addition to road development projects, other programs also sought to increase commerce in the region. One of these was the creation of Local Development Districts throughout Appalachia. Multicounty in their make-up, these districts were to "assist each State and its communities to plan for and administer effective social and economic development programs."101 Furthermore, it was believed that they would allow counties to pool their resources in order that they might be more efficiently used. ${ }^{102}$ Once these districts were developed, they were up to 75 percent funded by the Appalachian Act. This money was used to pay the salaries of the workers, as well as to provide technical assistance and training. In terms of how much money entering the state this amounted to, Development Districts within West Virginia received a total of $\$ 339,209$, those in Pennsylvania received a total of $\$ 313,700$, in Ohio the total was $\$ 245,570$, Alabama received $\$ 238,191$ and Tennessee received $\$ 233,966$ to round out the top five. ${ }^{103}$ Additionally, ARC policies allowed for certain areas to be named as "Growth Centers." These areas were situated propitiously so as to be centers for industry that was moving through the region. Within the Tug Valley area of West Virginia and Kentucky there was a belief that the area would benefit greatly if it received this ARC designation. According to a

\footnotetext{
${ }^{99}$ Ibid., 15.

${ }^{100}$ Ibid., 16-17.

${ }^{101}$ Appalachian Regional Commission, Appalachian Regional Commission Annual Report, 1967, Appalachian Regional Commission (Washington, D.C. July 1, 1966- June 30, 1967)71-74.

102 Ibid., 71-74.

${ }^{103}$ Ibid., 71-75.
} 
letter from Chamber of Commerce Managing Director Sid Copely to Governor Hulett Smith, being named a growth center would allow the Tug Valley area to "receive consideration for secondary benefits... which would provide flood protection for the Williamson, Tug Valley area." Copely went on to state that the area had "definite commitments for possible business expansion if we are provided necessary flood protection." 104

The building of new airports also received high acclaim from many local businesses and politicians as they saw these new or improved hubs as one more way in which commerce could enter and exit the region. In the 1967 ARC report 19 airports were to be upgraded so that they could handle "medium size jet traffic." 105 In West Virginia, this project gave both local and state politicians a chance to garner support as men such as Governor Hulett Smith, U.S. Senators Robert C. Byrd and Jennings Randolph, Congressman James Kee, as well as Mingo County's representative in the State Senate, Noah Floyd, all backed this proposal. ${ }^{106}$

In addition to his policies designed to deal with poverty in Appalachia, President Johnson also announced other policies which dealt with poverty in every area of the country. One of these was the Economic Opportunity Act of 1964. The act stated forthright that it was "the policy of the United States to eliminate the paradox of poverty in the midst of plenty...by opening to everyone the opportunity for education and training, the opportunity to work, and the opportunity to live in decency and dignity." ${ }^{107}$ It also created a vehicle through which these

\footnotetext{
${ }^{104}$ Sid Copely to Governor Hulett Smith, April 1, 1965, Hulett Smith Papers, West Virginia University Library, Morgantown, WV

${ }^{105}$ Ibid., 27-28.

106 "MC Airport Proposal Is Before ARC,” Williamson Daily News, January 18, 1966.

${ }^{107}$ Economic Opportunity Act of 1964, as amended, S 542-5, $91^{\text {st }}$ Cong., $2 \mathrm{~d}$ sess., 1.

This document is the act as amended through Dec. 30, 1969 and prepared for the Subcommittee on Employment, Manpower and Poverty
} 
stated objectives could be achieved, the Office of Economic Opportunity or OEO—which became the primary means for distributing funds and implementing programs associated with the War on Poverty.

When President Johnson announced the creation of the OEO to Congress, he also announced his intention to appoint Sargent Shriver, who had up until this point headed up the Peace Corps, as its director. ${ }^{108}$ The goals of the Economic Opportunity Act were extensive including making sure that, “...every individual has the opportunity to contribute to the full extent of his capabilities and to participate in the workings of our society" ${ }^{109}$ and as head of the OEO, Shriver was given wide-ranging control over what types of programs to implement in order to reach those goals. While he adopted community action, which would "[mobilize] people at the local level" and get "previously uninvolved people to work for their communities" ${ }^{\prime 10}$ he also focused on creating new programs to take the place of the old instead of trying to rework something that already existed. ${ }^{111}$

At the center of all of the programs, from the Community Action Programs to the Job Corps to Head Start programs, was the objective of self-help. The boards which ran the Community Action Programs were to be localized and ensure that "at least one-third of the members are persons chosen in accordance with democratic selection procedures adequate to assure that they are representative of the poor in the area served." 112 The Job Corps sought to

\footnotetext{
${ }^{108}$ Johnson, "Special Message to Congress Proposing a Nationwide War on the Sources of Poverty," The American Presidency Project. http://www.presidency.ucsb.edu/ws/?pid=26109

${ }^{109}$ Economic Opportunity Act of 1964, 1.

${ }^{110}$ Brauer, 110.

${ }^{111}$ Brauer, 118.

${ }^{112}$ Economic Opportunity Act, 29.
} 
provide employment opportunities to young people who would then be able to provide for their families in the future and not rely on public assistance. Finally, the Head Start programs intended to improve the educational opportunities for children of impoverished areas so that they might catch up with their counterparts in higher income areas and attain a higher level of education than their parents before them. The Office of Economic Opportunity was to facilitate these measures by "providing for basic education, health care, vocational training, and employment opportunities" 113 with the ultimate goal that people living in rural areas would be able to "remain in such areas and become self-sufficient therein."

The implementation of the Community Action Programs was to include the "maximum feasible participation" of those who were to be served by the programs with the idea that this would be the best means of ensuring that the groups served would "take full advantage of capabilities for self-advancement" and that the programs and projects were reaching their intended beneficiaries. ${ }^{115}$ One of the first programs put into action under the Economic Opportunity Act was Head Start. A branch of the Community Action Programs, Head Start programs were put in place for an 8 week summer program after it became clear that funding would remain from the first year of the War on Poverty. ${ }^{116}$ It quickly became clear that this was a successful undertaking of the OEO which still fit under the auspices of the Community Action Programs. While the idea for the program came from Washington, Head Start programs were generally overseen by local antipoverty agencies, with local schools running the programs. ${ }^{117}$ In

\footnotetext{
113 Ibid., 27.

114 Ibid., 27.

115 Ibid., 30.

${ }^{116}$ Frank Stricker, Why America Lost the War on Poverty-And How to Win It (Chapel Hill: The University of North Carolina Press, 2007), 68.

117 Ibid., 69.
} 
addition to providing education for children, the program also employed local parents as program aids, thereby providing additional income to families in the communities being served.

Yet despite Head Start's success in many areas of the country, there were still places where it was viewed as an assault upon the existing social structure. This was what happened in Mississippi where Frank Stricker states in his book, Why America Lost the War on Poverty - And How to Win It, that a number of different interests, including the "Child Development Group of Mississippi (CDGM), civil rights activism, community involvement, Head Start, and the War on Poverty came together in a remarkable movement."118 In the course of 1965, the CDGM opened up 83 Head Start centers ${ }^{119}$, a feat that was made even more impressive given the minimal support that local and state governments gave to the CDGM. Yet when the group attempted to engage in other aspects of the War on Poverty and expand Head Start to not only educate preschoolers, but also to "[mobilize] low-income blacks as aides, teachers and supporters" their efforts were quashed after only a year by segregationist efforts in the state. ${ }^{120}$

Still, Head Start endured throughout the War on Poverty and continues to exist today; other attempts at community action were not so long lived. In Mingo County, West Virginia, the local Economic Opportunity Commission (EOC) at first implemented programs which were both acceptable to and welcomed by local politicians. These included Head Start, a campaign to locate and enroll local residents who were eligible for Medicare called "Operation Medicare Alert,"121 and a project which utilized local men who were enrolled in the Aid to Dependent

\footnotetext{
118 Ibid., 70.

119 Ibid., 70 .

${ }^{120}$ Ibid., 70-71.

121 “EOC 'Operation Medicare Alert' Project Asked,” Bluefield Daily News, January 13, 1966.
} 
Children of the Unemployed (ADCU) to work as carpenters assistants. These men were employed tearing down abandoned and decrepit homes and shacks and rebuilding and repairing homes for low-income families in the area. The program was so successful that in a New York Times article from December 16, 1966, Marjorie Hunter reported that through its efforts, "66 buildings have been torn down and more than 60 houses built or repaired" ${ }^{\prime 22}$ over the course of about a year. However, after recognizing the limited effect of these programs the Mingo County EOC went a step further and opened a grocery cooperative in which members would be able to buy necessary goods at cost.

The grocery cooperative and other programs like it affected the local political and business powers and led to significant clashes between them and the EOC. The same New York Times article which had noted the success of the home building project also discussed the cooperative and the problems which the EOC had faced since opening it. Politicians as high up as United States' Senator Robert C. Byrd called for an investigation by the OEO and urged that the co-op not be allowed to accept food stamps ${ }^{123}$ which would have effectively limited the cooperatives ability to provide assistance to its target group. Eventually, the EOC won the battle and the cooperative was allowed to receive food stamps; however, the win did little to change the power structure of Mingo County. Proof of this came shortly thereafter when the cooperative's manager, R.F. Copely, was fired from his job as a school bus driver after he took community action a step further and helped to organize a union of bus drivers. ${ }^{124}$

\footnotetext{
${ }^{122}$ Marjorie Hunter, "Poor in West Virginia Town, Worried About the High Price of Food..." New York Times, December 16, 1966.

${ }^{123}$ David E. Whisnant, Modernizing the Mountaineer: People, Power, and Planning in Appalachia Rev. ed. (Knoxville: The University of Tennessee Press, 1994), 111.

${ }^{124}$ Ibid., 111.
} 
Elsewhere, the power structures also looked much like they always had. In Chicago, the War on Poverty program was firmly under the control of the local political machine, run by Mayor Richard Daley and so provided no more involvement for the poor than past programs had. ${ }^{125}$ The same was true in Pittsburgh, where the local community action organization was called the "Mayor's Committee on Human Resources" and was controlled by the mayor and city politicians. ${ }^{126}$ While these provide only a few examples of programs which failed to develop into true community action, or which were subdued when they started to, it becomes increasingly clear that politicians who were in power sought to maintain the status quo.

In a report by the President's National Advisory Commission on Rural Poverty one can again see this type of situation, in which patronage of a certain politician could help to determine where one worked and how much respect one had within a town. In their report, the commission discusses an example from a book called Grass Roots by Roscoe Martin in which Martin notes that in one small Kentucky community, the local schools provided "jobs for relatives, friends, and supporters of political leaders." ${ }^{127}$ It notes that being on the school payroll helped to give one leverage within the community. In Modernizing the Mountaineer, Whisnant also discusses this problem, noting that part of why the OEO struggled was related to the county political machines throughout Appalachia. He notes that some of these machines "siphoned off funds for unauthorized purposes; rejected programs considered contrary to their interests; hired friends, relatives and those who voted as they were told; and used their influence in the statehouses to

\footnotetext{
125 Stricker, 73 .

126 Ibid., 74.

${ }^{127}$ President's National Advisory Commission on Rural Poverty, Rural Poverty in the United States (Washington, D.C., May 1968), 119. The study sites p 4 of Martin's book during this discussion of local government.
} 
frustrate the efforts of reform-oriented individuals and groups." ${ }^{, 28}$ This lack of objectivity within county politics severely limited what the OEO, and in turn the War on Poverty, was able to achieve.

As with the Alliance for Progress, the War on Poverty talked a big game about the importance of self-help, but when it came to funding it seemed to make little difference if programs included the impoverished men and women of local communities or not. In West Virginia in 1966, three telegrams from the state's governor, Hulett Smith, to the Regional OEO office over a three month time frame accept funding for Mingo County's CAP, which had heavy involvement from local poor, as well as McDowell and Kanawha Counties' programs, which had far less involvement from the poor population. While Mingo County received a grant of $\$ 119,917$, McDowell County received $\$ 199,028$ and Kanawha County received a $\$ 108,667$ grant. ${ }^{129}$ With little to no distinction being made in terms of funding, involving the poor must have seemed an unnecessary inconvenience to those counties which already had agencies set up to handle anti-poverty programs.

Meanwhile, cities such as Chicago balked at the idea of including the poor in any sort of decision making process. Mayor Richard Daley insisted that "any program of this kind, in order to succeed, must be administered by the duly constituted elected officials of the areas with the cooperation of the private agencies." ${ }^{130}$ Professor David Zarefsky goes on to note in his work,

\footnotetext{
${ }^{128}$ Whisnant, 105.

${ }^{129}$ Governor Hulett Smith to Sidney H. Woolner, Western Union telegram, April 6, 1966; Governor Hulett Smith to Lawrence E. Williams, Western Union telegram; Governor Hulett Smith to Sidney H. Wooner, Western Union telegram, June 6, 1966, Box 26, Folder 4, Governor Hulett C. Smith Papers, West Virginia University Library.

${ }^{130}$ Quote from Chicago Mayor Richard Daley in David Zarefsky, President Johnson's War on Poverty: Rhetoric and History (Tuscaloosa: The University of Alabama Press, 1986), 123.
} 
President Johnson's War on Poverty: Rhetoric and History, that many mayors of big cities agreed with Mayor Daley. Zarefsky presents the example Mayor Briley of Nashville, Tennessee who "argued that the local government should in all cases be the grantee of funds, to achieve the highest degree of coordination and efficiency as well as to avoid administrative problems."131 This policy of filtering funds through the local government ensured that those who held political power would maintain that power, as they would be responsible for deciding who would receive allocations and how much each group received. Such a policy would replicate the structure of previous aid programs and allow for a continuation of the patronage politics that got many officials elected.

However, neither efforts by local politicians to appropriate control over poverty funds and exclude the poor from decision making, nor an absence of innovative programing stopped these local boards from receiving substantial funds. In Cleveland, where even the OEO recognized that there were issues about whether or not the poor were truly represented and continuously prodded the Council for Economic Opportunities in Greater Cleveland (CEO) until they ensured a wider representation of poor residents on their board, the CEO was allocated $\$ 3.25$ million. ${ }^{132}$ Yet the programs funded with this money were similar to welfare programs of the past as the CEO was "reluctant to argue with its powerful delegate agencies, and hence it has not made strong efforts to reform the existing programs." ${ }^{\text {133 }}$ Supporting existing programs which were clearly broken failed to encourage self-help or any sustainable change, leaving Cleveland

\footnotetext{
131 Zarefsky, 123.

${ }^{132}$ Senate Subcommitte on Employment and Manpower and the Committee on Labor and Welfare, Examination of the War on Poverty, Staff and Consultants Reports. Volume 6: Community Action Programs: Great Lakes, $90^{\text {th }}$ Cong., $1^{\text {st }}$ sess., 1967, 1853.

133 Ibid., 1863.
} 
and the surrounding areas in much the same state of poverty they had been in before the War on Poverty began.

Much like with the Alliance, the political and business elite refused to back most of the reforms that the War on Poverty sought to enact. Instead, they worked to reinforce the traditional power structures by using War on Poverty funds for traditional welfare programs. Thus, even where local poverty programs did exist, they often fell into the hands of the upperclasses and failed to involve the poor in the way Johnson's War on Poverty had originally envisioned. 


\section{Chapter 4 Saving Face and Recognizing Limitations}

Despite all the initial excitement about both the Alliance for Progress and the War on Poverty, each program's failures seemed to greatly outnumber its successes. For the Alliance for Progress, there was a shift from the revolutionary ideas that were put on paper at Punta del Este, to a much tamer Alliance, one that would be more broadly palatable to both Latin American elites and the U.S. companies who did business there. This transformation began to take shape even before the assassination of President Kennedy. For the War on Poverty, too, many of the hopes for diminishing poverty faded away in the light of the realities of diminished presidential power, unwilling local governments, and a war halfway around the world in Vietnam that just would not end. Both programs promised recipients, whether they were in Latin America or the United States, that this would be the time that government help was different, this would be that changed things for good. Yet in the end, these promises did no more than raise expectations only to dash them less than a decade later. While neither the War on Poverty nor the Alliance for Progress came crashing down, ending in a flaming disaster which someone could easily point to and say, "You see? This is what has become of the "decade of progress," both still ended, burning out slowly over the course of the late 1960s and even into the early 1970s both, leaving only a shadow where once there had been a great vision.

Throughout the Alliance era, one of the struggles the program faced was finding and keeping qualified personnel who believed in the Alliance or who were, at the very least, willing and able to promote it. From the very beginning, there were questions as to whether or not the Foreign Service members who worked in Latin America could be persuaded to promote the Alliance. In a memo to President Kennedy in June 1961, the President's Special Assistant 
Arthur Schlesinger noted that the men who made up the Foreign Service officers for Latin American affairs were both close knit and paternalistic, believing that they and they alone knew what was best for Latin America. He went on to state that they were "predominantly out of sympathy with the Alianza." ${ }^{134}$ In August of that same year, the topic was raised again in a memo from the Secretary of the Treasury, Douglass Dillon, to President Kennedy. Dillon stated that "It is of primary importance that the quality of U.S. personnel working on our aid programs in Washington and in the field be improved..."135 Two years later there were still a number of questions about Alliance staffing and in a memo to President Kennedy, Richard Goodwin stated, "Probably the most serious single problem is personnel. The Alianza has the same trouble as the Washington Nats - they don't have the ballplayers...there is also a tremendous amount of mediocrity in high places." "136 The Washington Senators, or the Nats, won 56 games that season and lost 106, not exactly a record the Alliance was hoping to mirror with its programs. ${ }^{137}$

This problem of enthusiastic personnel went all the way to the top and after the assassination of Kennedy the Alliance lost some momentum, causing the program to stutter only two short years into its life despite President Johnson's early promises of support for the Alianza. This was not surprising, President Johnson had his own agenda and his own goals, both within the Alliance and in other areas. It soon became clear that there was a shift within the Alliance in terms of what was truly important. In some ways this shift had begun even before Johnson took

\footnotetext{
134 “Memorandum from the President's Special Assistant (Schlesinger) to President Kennedy," June 27, 1961, Foreign Relations of the United States, Volume XII, American Republics, Document 13.

135 "Memorandum from Secretary of the Treasury Dillon to President Kennedy," August 25, 1961, Foreign Relations of the United States, Volume XII, American Republics, Document 32.

136 "Memorandum from the Secretary General of the International Peace Corps Secretariat (Goodwin) to President Kennedy," September 10, 1963, Foreign Relations of the United States, 1961-1963, Volume XII, American Republics, Document 63.

${ }^{137}$ Baseball Almanac, “1963 Washington Senators Schedule," Baseball Almanac, http://www.baseballalmanac.com/teamstats/schedule.php? $\mathrm{y}=1963 \& \mathrm{t}=\mathrm{WS} 2$ (accessed July 4, 2013).
} 
office. In his essay, "U.S. Relations with Latin America," Joseph Tulchin states that, "Kennedy himself had become disillusioned with the Wilsonian policy of intervention on the side of democracy." 138 This, in turn, contributed to the focus of policy moving away from the goal of building democracies and towards a more intense emphasis on the prevention of communism and the promotion of trade. In a joint statement issued by Kennedy and the president of Bolivia, Victor Paz Estenssoro, the two noted their "grave concern at setbacks to democratic government in Latin America" 139 however, what to do about this was left to the vague concept of "a need to contribute to the preservation and strengthening of democratic institutions." ${ }^{\prime 140}$ Meanwhile, the two discussed much more in depth ways to spark the economy of Bolivia.

Soon after, in a speech to a group in Texas on November 22, 1963, the day of his assassination, President Kennedy promoted the Alliance as an efficient way of preventing the spread of communism, stating that without it, "the Communist advance onto the mainland of South America would long ago have taken place." ${ }^{141}$ While these speeches still mention the importance of democracy, there is a much more limited investment in the promotion of democratic governments than there was at the advent of the Alliance. Following the assassination of President Kennedy, the outlook for the promotion of democracy became grimmer still. On November 26, 1963, Lyndon Johnson made one of his very first speeches as president to members of the Latin American diplomatic community. In that speech, President

\footnotetext{
${ }^{138}$ Joseph S. Tulchin, "U.S. Relations with Latin America," in Lyndon Johnson Confronts the World: American Foreign Policy, 1963-1968, ed. Warren I. Cohen and Nancy Bernkopf Tucker (Cambridge: Cambridge University Press, 1994), 240.

${ }^{139}$ John F. Kennedy: "Joint Statement Following Discussions With the President of Bolivia.," October 23, 1963. Online by Gerhard Peters and John T. Woolley, The American Presidency Project. http://www.presidency.ucsb.edu/ws/?pid=9490.

${ }^{140}$ Ibid.

${ }^{141}$ John F. Kennedy: "Remarks at the Breakfast of the Fort Worth Chamber of Commerce.," November 22, 1963. Online by Gerhard Peters and John T. Woolley, The American Presidency Project. http://www.presidency.ucsb.edu/ws/?pid=9538.
} 
Johnson reiterated the United States' commitment to Latin America through the Alliance for Progress, a commitment which Kennedy had made three years earlier. Yet while Kennedy had stated the importance of democracies throughout the region, President Johnson did not mention democratic governments. Instead stating that the first principles agreed upon at Punta del Este was "the right of every American nation to govern itself free from outside dictation or coercion from any quarter." ${ }^{142}$ He thereby established a connection between his administration and a policy of nonintervention, but not a connection to the promotion of democratic principles.

By March of 1964 the press was having a field day with statements attributed to the new administration. In a New York Times article written by Tad Szulc it was reported that the United States was "...considering modification of its policy of actively opposing rightist and military dictatorships that might emerge in the future in Latin America." ${ }^{143}$ Szulc further asserted that Thomas Mann, the Assistant Secretary of State for Inter-American Affairs, had referred to "four purposes United States policy in Latin America should serve.” These included: fostering economic growth, protecting current U.S. investments, not intervening in internal political affairs, and opposing communism. ${ }^{144}$ Tulchin's essay also notes Mann's propensity to discount democracy in favor of stability, discussing how Mann's appointment to the Johnson administration led to many Kennedy appointees leaving, with those who stayed sharing a belief in the importance of power and security and seeing the pragmatism in "sacrificing support for democracy to other priorities in the formulation of U.S. policy in specific cases or toward

\footnotetext{
${ }^{142}$ Lyndon B. Johnson: "Remarks on the Alliance for Progress to Representatives of the Countries of Latin America.," November 26, 1963. Online by Gerhard Peters and John T. Woolley, The American Presidency Project. http://www.presidency.ucsb.edu/ws/?pid=26785

${ }^{143}$ Tad Szulc, "U.S. May Abandon Effort to Deter Latin Dictators," New York Times, March 19, 1964.

${ }^{144}$ Ibid.
} 
specific countries." 145 The White House attempted to counter the reputation which was beginning to form as a result of Mann's position by issuing a statement on the same day that the Szulc article was published which stated: "United States devotion to the principles of democracy is an historical fact. United States policy toward unconstitutional governments will as in the past be guided by the national interest and the circumstances peculiar to each situation as it arises." ${ }^{146}$ To those who had counted on the United States to unequivocally support democracy, this statement was a bit of a letdown, no matter how true it was in practice. By mid-May 1964 significant damage had been done and the Latin American press had picked up the story with an editorial in the publication Expreso out of Peru echoed many of the points made in Szulc's article, including discussion of the four goals which Mann allegedly thought U.S. policy should pursue. $^{147}$

Yet the U.S. policy remained the same. A Policy Information Statement from June 1964 stated, "Assistant Secretary Mann in major U.S. policy statement says U.S. will continue to seek to discourage those conspiring to overthrow constitutionally elected governments but, if governments are overthrown U.S. will continue to encourage holding of free and fair elections." ${ }^{\prime 18}$ This was a far cry from the statements made at Punta del Este which stated that the Alliance for Progress was "established on the basic principle that free men working through the institution of representative democracy can best satisfy man's aspirations" and that the Alliance countries would work towards both improving and strengthening "democratic institutions

\footnotetext{
145 Tulchin in Lyndon Johnson Confronts the World, 221.

${ }^{146}$ Circular telegram 1730, March 19; National Archives and Records Administration, RG 59, Central Files $1964-$ 66, POL 1 US.

147 "Press Commentary on Alleged Change in U.S. Policy Towards Latin America," May 15, 1964, RG 59, Pol $1-$ LA - US, Box 2416.

${ }^{148}$ Policy Information Statement ARA-314, National Archives and Records Administration, June 12, 1964, RG 59, Pol 1 LA-US, Box 2416.
} 
through application of the principle of self-determination by the people."149 Instead, it was quickly becoming clear that there were limits on how much the Alliance could do, and how much the U.S. would support, in terms of helping to create democracies.

In fact, despite government statements, the Kennedy-era focus on democracy became noticeably absent from the Johnson-era Alliance for Progress. Instead, Johnson's speeches focused increasingly on trade and ensuring that new, private investment was taking hold in Latin America with Tulchin noting that "Johnson had little interest in the sweeping reforms that underlay the Alliance for Progress" choosing instead to rely on more cautious approaches which were espoused by the businessmen he came to rely upon. ${ }^{150}$ In his speech on the $5^{\text {th }}$ Anniversary of the Alliance for Progress there was no mention of democracies, yet trade was discussed repeatedly with focus being turned to economic problems and solutions, such as the administration's insistence that the U.S. participate more effectively in the International Coffee Agreement, its recommendation that Congress do away with the import fee on sugar and its removal of quota restrictions on lead and zinc. President Johnson also focused on tangible evidence of progress, such as how the Alliance had helped governments to build 130,000 more homes, irrigated 136,000 more acres of farmland and provided classrooms for 1 million students. $^{151}$

\footnotetext{
${ }^{149}$ Inter-American Economic and Social Council (IA-ECOSOC), Alianza para el Progreso: The Record of Punta del Este, 1961, 1-2.

${ }^{150}$ Tulchin in Lyndon Johnson Confronts the World, 224-225.

${ }^{151}$ Lyndon B. Johnson: "Statement by the President on the Fifth Anniversary of the Alliance for Progress," March 14, 1966. Online by Gerhard Peters and John T. Woolley, The American Presidency Project. http://www.presidency.ucsb.edu/ws/?pid=27488.
} 
However while the numbers presented to the public looked promising, other numbers presented a different story and raised questions about the Alliance's effectiveness. In 1965 a State Department communication noted that in Peru inflation was increasing and prices had risen 6\% a year between 1960-1963, but by 1964 it was $10 \%$ and it was expected that in 1965 prices would rise between $15 \%$ and $20 \% .^{152}$ In terms of housing, an AID audit stated that "The housing shortage in Latin America is growing at an alarming pace. Not only has new housing construction failed to keep pace with the increasing needs... but it has failed to alleviate the shortage which existed prior to the Alliance." ${ }^{153}$ In terms of numbers this meant that in Brazil there was a shortage of 8 million homes and each year it was growing at a rate of 450,000 units. In Colombia there was a shortage of 350,000 and it was growing at a rate of 55,000 units a year. ${ }^{154}$ These numbers did not reflect the picture of progress that the Johnson administration was attempting to portray.

The Johnson administration also began to put a stronger emphasis on the role the military could play in development. While from the beginning the Alliance had looked towards national militaries as a group which could, if "persuaded that their support for economic and social reform is essential to the establishment of democratic, anti-Communist, secure societies...go far to assure the success of this program"155 under the Johnson administration this expanded to become a more comprehensive line of policy. This did not necessarily mean a buildup of Latin American militaries, but instead advocated for them to play a larger role in modernizing

\footnotetext{
152 "Updating of Embassy's Assessment of Campesino Situation and U.S. Programs in Relation Thereto," November 10, 1965, National Archives and Records Administration, RG 59, Pol 13-2, Box 2412.

${ }^{153}$ Committee on Government Operations, "U.S. AID Operations in Latin America Under the Alliance for Progress," $90^{\text {th }}$ Congress, 2d Session, 28.

${ }^{154}$ Ibid., 28.

155 "Telegram From the Embassy in Mexico to the Department of State," Foreign Relations of the United States, Volume XII, American Republics, Document 34.
} 
societies. W.W. Rostow noted this during the $2^{\text {nd }}$ Meeting of the Senior Interdepartmental Group on September 28, 1967 when he discussed how "the military play an important role in the countries" and that they "can be a force for progress." 156 Ideally, this would have meant that the militaries would have become "guardians of constitutional order and agents of constructive change" 157 and played a role like that of the Army Corps of Engineers in the United States, however this goal was not recognized.

Instead of ensuring that elected governments would be safe and that democratic processes would be protected, this increased stress on the military's role in modernizing societies contributed to an increasing number of governments which supported conservative policies which benefited those classes which had long held power in Latin American nations. By 1970 roughly half of the nations of Latin America were run by dictators, military juntas, or those who fixed elections to maintain power. Many of these governments were supported by the United States so long as they remained committed to anti-Communism. Yet in supporting them, the U.S. contradicted the very principles that had been agreed upon at Punta del Este. In an essay titled "Reflections," Arturo Morales Carrión discussed the lack of political understanding about the Alliance and how without high level political meetings early, by the time one was held in 1967 “it was too late: Economic development and political democracy had already begun to part ways." 158 By recognizing and aiding governments which were supportive of development but disinterested in social progress or political democracy, the United States showed Latin

\footnotetext{
156 "Record of Discussion and Decisions of $22^{\text {nd }}$ Meeting of the Senior Interdepartmental Group," September 28 , 1967, Foreign Relations of the United States 1964-1968, Volume XXXI, South and Central America; Mexico, Document 65. At the time, Rostow was serving as the Special Assistant to the President.

157 “Department of State Guidelines Paper," Foreign Relations of the United States, Volume XII, American Republics, Document 45.

${ }^{158}$ Ernesto Betancourt and others, "Reflections" in The Alliance for Progress: A Retrospective, ed. L. Ronald Scheman (New York: Praeger, 1988), 197.
} 
Americans that it was not serious about the commitments to social justice which had been made at Punta del Este and as focus became ever more concentrated on ensuring economic development, the political objectives of the Alliance for Progress became lost. Carrión notes this occurrence, "despite the fact that making Latin America a region of functional, vital democracies was of the essence." 159

The Alliance for Progress did not create these democracies. Nine years earlier, when the Alliance was young and held within it the hopes of not just an administration, but of multiple nations and millions of people, the Chairman of the Task Force on Latin America, Adolf Berle had stated in a letter to President Kennedy that:

The present struggle will not be won, and can be lost, by opportunist support of transitory power-holders or forces whose objectives are basically hostile to the peoples they dominate. Success of the American effort in Latin America requires that at all times its policy be based on clear, consistent, moral democratic principles. I do not see that any other policy can be accepted or indeed stands any real chance of ultimate success. ${ }^{160}$

Yet, as the United States government began to see the international environment as increasingly hostile it turned away from these principles and focused more on keeping friendly governments in power then helping foster the revolutions it had originally called for. Berle went on to state that, "The forces sweeping Latin America today demand progress, and a better life for the masses of their people, through evolution if possible, or through revolution if that price must

\footnotetext{
${ }^{159}$ Ibid., 197.

${ }^{160}$ Chairman of the Task Force on Latin America Adolf Berle to President John F. Kennedy, July 7, 1961, FRUS XII, American Republics, 43, Document 16.
} 
be paid." ${ }^{161}$ When the promised reforms of the Alliance for Progress failed to fully materialize, Berle's words echoed as an eerily accurate prophecy. The U.S. support of dictators and other governments which consistently showed a disregard for the rights of their people led not to democratic progress, but to violent revolutions, both during and after the Alliance years. Unfortunately, this political chaos allowed many politicians who balked at the ideas of social progress espoused by Punta del Este, to remain in power and further limit rights in the name of providing stability.

While the Alliance for Progress sputtered along during President Johnson's administration, the president made every effort to keep his War on Poverty from facing the same fate. Yet despite his efforts, the War on Poverty was overshadowed by Vietnam, as well as dissent at home. While the program had received significant support at first, the attempts made in its name to combat the causes of poverty, not just the symptoms aroused a number of local powerhouses which made it their goal to prevent the War on Poverty from enacting real change. Instead, within Appalachia, these business leaders and local politicians tended to favor the top down approach of the ARC, which had first made suggestions to President Johnson, over the bottom up approach of the War on Poverty, which encouraged all members of the local community, no matter what class they belonged to, to involve themselves in the fight against poverty and in finding innovative ways to help improve their towns.

In many ways, this was because ARC programs reinforced the traditional power structure, while the War on Poverty threatened to upset it. The business friendly policies of the ARC ensured that community leaders, both in the political and business realms, would be able to

\footnotetext{
${ }^{161}$ Ibid., 43.
} 
continue to hold the power within their communities. On the other hand, in many parts of Appalachia, where patronage politics were a way of life, the War on Poverty threatened to disturb the political hierarchy by changing how aid was distributed and who controlled it. In West Virginia cronyism had a long history and as the memoir of the director of the Mingo County director of the OEO, Huey Perry, shows, they expected jobs to be handed out and aid to be given as a reflection of one's political affiliations. In Perry's memoir, one employee of a welfare program, known locally as the crash program, in which men were employed in labor intensive, menial tasks such as pulling weeds, cleaning ditches and digging graves for a dollar an hour, is quoted as saying "You just can't get a thing out of that welfare department lessen you vote for Noah Floyd's gang, and then it's so little you can't get by on it." ${ }^{\text {162 }}$ This point is reiterated in Jerry Bruce Thomas's book, An Appalachian Reawakening, in which Thomas notes that participants in the same crash programs mentioned before told an interviewer that "...the notorious local political machine used the ADCU jobs as patronage to stay in power, subjecting recipients to intimidation and humiliation." 163

Elsewhere in Appalachia nepotism was also a problem as well. In Modernizing the Mountaineer, Whisnant discusses the differences between the model that the Council of Economic Advisors out of the OEO used to explain poverty and the model that would have actually explained poverty. Whisnant's model stated:

Corporate monopolization of major resources

leads to

an inequitable and undemocratic economic and

\footnotetext{
${ }^{162}$ Huey Perry, They'll Cut Off Your Project: A Mingo County Chronicle (New York: Praeger Publishers, 1972), 23.

${ }^{163}$ Jerry Bruce Thomas, An Appalachian Reawakening: West Virginia and the Perils of the New Machine Age, 1945-1972 (Morgantown: West Virginia University Press, 2010), 147
} 


$$
\begin{gathered}
\text { political system } \\
\text { which leads to } \\
\text { political powerlessness, economic and cultural exploitation } \\
\text { and environmental destruction } \\
\text { which lead to } \\
\text { poor education and social services, minimal income, } \\
\text { hopelessness, and out-migration } \\
\text { which facilitate further } \\
\text { Corporate monopolization of major resources. }{ }^{164}
\end{gathered}
$$

The corporate monopolization and the inequitable and undemocratic political systems he speaks of were the result of favoritism within local politics. Throughout the region, Whisnant cites the way in which public money ended up in private hands, stating that with both the New Deal and other welfare programs federal money was disbursed by "relatively unaccountable local officials in such a way as to reinforce and extend their own political power."165

When one looks at the careers of a number of Appalachian politicians it becomes evident that the number of career politicians was very high and that most of these men were well connected with big business within their regions. In West Virginia, in the $5^{\text {th }}$ District, the family Congressman James Kee held a seat in the U.S. House of Representatives for forty years, from his father's election in 1932 until Kee's defeat in the election of 1972 by Ken Heckler. Heckler himself served in the U.S. Congress from 1959 through 1977. As for the state's representatives to the U.S. Senate, Robert C. Byrd held his seat from 1959 until his death in 2010. One resident of Mingo County summed it up in a letter to the local newspaper, "The next election is over...when the confirmation period shall come the total majority will read the same. There will

\footnotetext{
${ }^{164}$ Whisnant, 98-99.

${ }^{165}$ Ibid., 104-105.
} 
be no change in the majority, only the image of issue and the detail of tallying remain to be completed." ${ }^{166}$ In Kentucky this same pattern held true with U.S. Senators holding significantly shorter terms than Senator Byrd, but with many house members serving for two decades or more. This was the case with Representative Frank Chelf, who served from 1945-1967 and Gene Snyder who served for a total of 22 years, from 1963-1965 and then from 1967-1987.

Representative Brent Spence left office just before the War on Poverty began, but served for 32 years, from 1931-1963. ${ }^{167}$ With many politicians serving such extended times in office, they often had a substantial stake in the status quo. Whisnant reiterates this, stating that, “...many Appalachian counties had developed powerful political machines in whose interest it was to avoid the structural reforms that could have helped eliminate poverty." ${ }^{168}$ Projects initiated by the OEO which threatened the balance of power as it was were more than enough to incite outrage in local politicians. Thus local governments often sought significant control over the projects initiated under the auspices of the War on Poverty. When they were unable to achieve this, they rebelled against the War on Poverty in an attempt to reassert power.

Yet it was not only the political elite who worked to maintain the status quo. Throughout Appalachia and other high poverty areas, big corporations fought to keep costs low and profits high. In Appalachia, the main business behind this fight was coal. In small towns up and down the mountains, coal companies provided the few jobs that existed. According to Thomas Kiffmeyer, they "dominated the Appalachian economy, monopolized its political resources, and

\footnotetext{
166 “Readers Write" Letter from Claude Cark, Williamson Daily News, February 3, 1966.

${ }^{167}$ All information comes from the Biographical Directory of the United States Congress, http://bioguide.congress.gov, Accessed July 4, 2013.

${ }^{168}$ Whisnant, 105.
} 
could mobilize against threats to their hegemony."169 Furthermore, these large companies made certain that they were well represented within the political system, donating significant funds to politicians which “....was traded for favorable treatment of corporations by, for example, county judges, tax assessors, and planning boards..." ${ }^{170}$ With the influx of federal money that came from the War on Poverty, the coal companies shared with local political powers the desire that the money be closely controlled by those who already held power. Where groups such as the Appalachian Volunteers (AV) worked to undermine this hierarchy, such as Pike County, Kentucky, they were swiftly discredited and faced threats to their life and property. Kiffmeyer points out that because Pike County was "the headquarters of the National Independent Coal Operators' Association and was one of Kentucky's largest coal-producing counties, the leaders of the business community... stood to lose a great deal if the AV succeeded."171

\footnotetext{
${ }^{169}$ Thomas J. Kiffmeyer, "From Self-Help to Sedition: The Appalachian Volunteers in Eastern Kentucky, 19641970," The Journal of Southern History 64, no. 1 (February 1998), 68.

${ }^{170}$ Whisnant, 105.

${ }^{171}$ Kiffmeyer, 91 .
} 


\section{Chapter 5 Conclusion}

The problem with the ideal of self-help was not the beliefs behind it or the policies that it bred. Instead, the problem with self-help was the unwillingness of governments, both in the United States and in Latin America, both federal and local, to truly embrace it. These same problems became the legacy of implementing modernization theory as a political policy. When President Kennedy announced the Alliance for Progress he proclaimed a new era for interAmerican relations. An era based upon respect and a common goal—a better standard of living for all Americans and a legacy which leaders and common men alike could be proud to pass on to their children. Instead, as the Alliance for Progress was implemented it sought out projects for approval which had little to do with local communities. Governments talked about development in big terms - industry, roads, trade — and objectives such as agrarian reform and education were pushed aside, paid lip service, but pursued with little of the enthusiasm which went into the modernization of sectors which had a bigger payoff.

Domestically there were men and women who were excited to be a part of Community Action Programs. There were young people who wanted to fight the War on Poverty and there were communities which were desperate for changes which would make them more vital. But in the end, this too was a losing battle. While President Johnson struggled to make his Great Society a priority, Vietnam ate away at his political capital and at his War on Poverty. Again and again Congress looked at the CAPs and other War on Poverty programs and cut funding, citing the necessity of its use elsewhere. But even more than funding issues, this domestic attempt to fight the causes of poverty led to protests from local governments across the nation, and most notably in Appalachia. Men whose families had been entrenched in power for 
generations were happy with the status quo and were not about to allow groups of poor residents, led by people they called "outsiders" to change their financial and political standing.

Both the Alliance for Progress and the War on Poverty were idealistic programs promoted by presidents who wished to improve the lives of the poor. They were created in such a way as to encourage individuals to take an interest and a lead in finding solutions to the problems their communities faced and to create better lives for themselves and their families. Yet while both seemed promising, neither program made it out of the $1960 \mathrm{~s}$. While there were a number of reasons why the Alliance for Progress and the War on Poverty were slowly phased out, the implications of their disappearances were felt across the Americas. Once again, the United States government had failed to uphold promises in Latin America, this led people to question future U.S. aid programs more thoroughly and be less open to new programs that were introduced. Domestically, as well, people felt let down and abandoned. Many had used War on Poverty programs to try and change their local communities, but in the absence of such programs, long-time political powerhouses continued to run small towns across the United States. The same held true for Latin America, where dictatorships born in Alliance years but with no trace of the democratic requirements discussed at Punta del Este held control of nations. Neither the Alliance, nor the War on Poverty changed the basic power structures and in their wake, revolutions would continue as nations and individuals continued to seek better lives and basic rights.

In the end, the question we are left with is whether or not the Alliance for Progress or the War on Poverty ever truly stood a chance, and to answer that is to answer whether modernization 
theory can ever be successful as policy, instead of simply theory. In order to answer this, one must decide whether or not he or she truly believes that a nation which has reached the apex of modernization is truly able to help another nation along, and even if it is, whether there is any nation which will do so with the full awareness that acting in such a way will breed more competition long term and will make it more difficult to access necessary raw materials at a cheap price. While Rostow states that the preconditions for take-off often arise from "some external intrusion by more advanced societies" which "shock the traditional society" and "set in motion ideas and sentiments which initiate the process by which a modern alternative to the traditional society was constructed out of the old culture" $" 172$ he does not insinuate that this intrusion is a positive one, in fact, quite the opposite, he notes how it is often the result of wars or exploration and exploitation. There is no guarantee that the country which intrudes will ever become magnanimous towards the nation it entered.

When modernization theory was implemented as the way in which Latin America could develop quickly and the way that impoverished parts of the U.S. could catch up, so to speak, with their urban counterparts, it was new and untested as a policy option. Rostow and Millikan's book A Proposal had come out in 1957 and the proposals it listed were, in large part, no more than theory. The studies which had been completed had been done in India, Indonesia and Italy—nations which were far from Latin America, both geographically and culturally. ${ }^{173}$ However it is possible that modernization theory could have overcome the differences, after all, its principles were based upon the idea that throughout the world outside of the United States there had been a "pattern of society [that] remained essentially fixed in the mold of low-

\footnotetext{
172 Rostow, 6.

${ }^{173}$ Millikan and Rostow, vii.
} 
productivity rural life centered on isolated villages" with political activity "confined to an extremely small elite." ${ }^{174}$ Yet in the second chapter of their work A Proposal, Rostow and Millikan discuss in depth the misconceptions that were likely to be associated with modernization theory and the necessity of avoiding them. The last of these pitfalls is described as "a final and serious misconception which exposes proposals for economic programs to attack is that revolt and protest are the result of hunger and poverty; that relieving hunger and reducing poverty will reduce revolutionary pressures." ${ }^{" 175}$ U.S. policy undeniably subscribed to this belief, at least in part. This, in turn, led to very high expectations for what the Alliance should do and for what the War on Poverty should be able to achieve and a reality that was far different in both cases.

When one looks back, the legacies left by the Alliance for Progress and the War on Poverty are mixed, at best. Here and there are programs which were left behind from the "decade of development"-Head Start, housing developments, and highways - to name a few. Yet more than anything else, the legacy left behind by these efforts was a recognition of the limitations of government. In the years that have passed since the Alliance for Progress and the War on Poverty were in their primes, there have been a number of piecemeal efforts to do what they did —attempts to limit poverty, provide aid, and encourage development. However none of these have even approached the scope of the Alliance or the War on Poverty. Instead, the failure of both programs has reminded generation after generation that there is a limit on what can be achieved, even when a government has the best of intentions.

\footnotetext{
${ }^{174}$ Ibid., 4.

${ }^{175}$ Ibid., 19.
} 


\section{Bibliography}

Air Force Personnel Center. "Legion of Merit." Air Force Personnel Center http://www.afpc.af.mil/library/factsheets/factsheet.asp?id=7732 (accessed May 23, 2013).

Appalachian Regional Commission. Appalachian Regional Commission Annual Report, 1966. Prepared by the Appalachian Regional Commission. Washington, DC: Government Printing Office, 1966.

Baily, Samuel L. The United States and the Development of South America, 1945-1975. New York: New Viewpoints, 1976.

Baseball Almanac. "1963 Washington Senators Schedule.” Baseball Almanac. http://www.baseball-almanac.com/teamstats/schedule.php?y=1963\&t=WS2 (accessed July 4, 2013).

Benmergui, Leandro. "The Alliance for Progress and Housing Policy in Rio de Janeiro and Buenos Aires in the 1960s.” Urban History 36 (2009): 303-326.

Bluefield Daily News

Brauer, Carl M. "Kennedy, Johnson, and the War on Poverty." The Journal of American History 69, no. 1 (June, 1982): 98-119.

Cohen, Lizabeth. A Consumer's Republic: The Politics of Mass Consumption in Postwar America. New York: Vintage Books, 2004.

Constigliola, Frank. "Lyndon B. Johnson, Germany, and 'the End of the Cold War." In Lyndon Johnson Confronts the World: American Foreign Policy, 1963-1968, edited by Warren I. Cohen and Nancy Bernkopf Tucker, 173-210. Cambridge: Cambridge University Press, 1994.

Evans, Rowland and Robert Novak. Lyndon B. Jonson: The Exercise of Power. New York: The New American Library, 1966.

Governor Hulett C. Smith Papers. West Virginia and Regional History Collection. West Virginia University, Morgantown.

Harrington, Michael. The Other America: Poverty in the United States. New York: The Macmillan Company, 1963.

Inter-American Economic and Social Council. Alianza para el Progreso: The Record of Punta del Este. Punta del Este: The Pan American Union and the Agency for International Development, 1961.

Ish-Shalom, Piki. "Theory Gets Real, and the Case for a Normative Ethic: Rostow, Modernization Theory, and the Alliance for Progress." International Studies Quarterly 50 (2006): 287-311. 
Kiffmeyer, Thomas J. "From Self-Help to Sedition: The Appalachian Volunteers in Eastern Kentucky, 1964-1970.” The Journal of Southern History 64, no.1 (February 1998): 6594.

LaFeber, Walter. Inevitable Revolutions: The United States in Central America. $2^{\text {nd }}$ ed. New York: W.W. Norton and Company, 1993.

Latham, Michael E. "Ideology, Social Science, and Destiny: Modernization and the Kennedy Era Alliance for Progress." Diplomatic History 22, no. 2 (Spring 1998): 199-229.

Levinson, Jerome and Juan de Onís. The Alliance that Lost its Way: A Critical Report on the Alliance for Progress. Chicago: Quadrangle Books, 1970.

National Archives and Records Administration, College Park, Maryland.

Record Group 59, Records of the Department of State

Record Group 43, Official Records of CIAP 1964-1968

New York Times

Perry, Huey. "They'll Cut Off Your Project": A Mingo County Chronicle. New York: Praeger Publishers, 1972.

Rabe, Stephen G. Eisenhower and Latin America: The Foreign Policy of Anticommunism. Chapel Hill: The University of North Carolina Press, 1988.

Rostow, W.W. The Stages of Economic Growth: A Non-Communist Manifesto. $2^{\text {nd }}$ ed. Cambridge: Cambridge University Press, 1971.

Rostow, W.W. and Max F. Millikan. A Proposal: Key to an Effective Foreign Policy. New York: Harper \& Brothers, 1957.

Scheman, L. Ronald, ed. The Alliance for Progress: A Restrospective. New York: Praeger, 1988.

Stricker, Frank. Why America Lost the War on Poverty—And How to Win It. Chapel Hill: The University of North Carolina Press, 2007.

The American Presidency Project. Online by Gerhard Peters and John T. Woolley. http://www.presidency.ucsb.edu/.

Taffet, Jeffrey F. Foreign Aid as Foreign Policy: The Alliance for Progress in Latin America. New York: Routledge, 2007. Kindle edition.

Thomas, Jerry Bruce. An Appalachian Reawakening: West Virginia and the Perils of the New Machine Age, 1945-1972. Morgantown: West Virginia University Press, 2010. 
U.S. Congress. House. Subcommittee on International Finance; Committee on Banking and Currency. Development of Cooperative Enterprises, 1966. Implementation of the Humphrey Amendment to the Foreign Assistance Act of 1961. Fifth Annual Report to the Congress, Fiscal Year 1966. $90^{\text {th }}$ Cong., $1^{\text {st }}$ sess., 1967. Washington, D.C., Government Printing Office.

U.S. Congress. Senate. Committee on Labor and Public Welfare. Economic Opportunity Act of 1964, as amended. $91^{\text {st }}$ Cong., 2 d sess., 1970. Washington, D.C., Government Printing Office.

U.S. Congress. Senate. Subcommittee on Housing; Committee on Banking and Currency. Study of International Housing. $88^{\text {th }}$ Cong., $1^{\text {st }}$ sess., 1963. Washington, D.C., Government Printing Office.

U.S. State Department. Foreign Relations of the United States. http://history.state.gov/historicaldocuments/about-frus.

Wells, Wyatt. American Capitalism, 1945-2000: Continuity and Change from Mass Production to the Information Society. Chicago: IVAN R. DEE, 2003.

Whisnant, David E. Modernizing the Mountaineer: People, Power, and Planning in Appalachia. Rev. ed. Knoxville: The University of Tennessee Press, 1994.

Williamson Daily News 